\title{
Industrial Symbiosis and Energy Efficiency in European Process Industries: A Review
}

\author{
Teresa Annunziata Branca ${ }^{1}$, Barbara Fornai ${ }^{1}$, Valentina Colla ${ }^{1, *} \mathbb{C}$, Maria Ilaria Pistelli ${ }^{2}$, Eros Luciano Faraci ${ }^{2}$, \\ Filippo Cirilli ${ }^{2}$ and Antonius Johannes Schröder ${ }^{3}$ (i)
}

1 Scuola Superiore Sant'Anna, TeCIP Institute, 56124 Pisa, Italy; teresa.branca@santannapisa.it (T.A.B.); barbara.fornai@santannapisa.it (B.F.)

2 RINA CONSULTING—Centro Sviluppo Materiali S.p.A. (CSM), 00128 Roma, Italy; ilaria.pistelli@rina.org (M.I.P.); eros.faraci@rina.org (E.L.F.); filippo.cirilli@rina.org (F.C.)

3 Sozialforschungsstelle, Technische Universität Dortmund, D-44339 Dortmund, Germany; antonius.schroeder@tu-dortmund.de

* Correspondence: valentina.colla@santannapisa.it; Tel.: +39-348-071-8937

Citation: Branca, T.A.; Fornai, B.; Colla, V.; Pistelli, M.I.; Faraci, E.L.; Cirilli, F.; Schröder, A.J. Industrial Symbiosis and Energy Efficiency in European Process Industries: A Review. Sustainability 2021, 13, 9159. https://doi.org/10.3390/su13169159

Academic Editors: Helena Carvalho, Michael Martin and Radu Godina

Received: 1 July 2021

Accepted: 11 August 2021

Published: 16 August 2021

Publisher's Note: MDPI stays neutral with regard to jurisdictional claims in published maps and institutional affiliations.

Copyright: (c) 2021 by the authors. Licensee MDPI, Basel, Switzerland. This article is an open access article distributed under the terms and conditions of the Creative Commons Attribution (CC BY) license (https:// creativecommons.org/licenses/by/ $4.0 /)$.

\begin{abstract}
Over the last few decades, process industries have invested increasing efforts in developing technical and operating solutions related to industrial symbiosis and energy efficiency in both production processes and auxiliary services. In particular, new technologies that enable industrial symbiosis, such as novel treatment processes for byproduct extraction and valorization, water purification, and energy transformation, were implemented in different sectors. This work analyses recent relevant results in the implementation of industrial symbiosis and energy efficiency solutions within process industries across Europe, based on the transactions of energy and material flows. Current developments, based on the circular economy's transformation levers and related achieved results, were taken into account by considering the achieved results coming from the literature, EU-funded projects, programmes, and initiatives on the implementation of technical solutions and practices related to industrial symbiosis and energy efficiency. In addition, the most relevant challenges deriving from the implementations of industrial symbiosis and energy efficiency were analysed. A comprehensive picture of the sectors involved in achieving more proactive cross-sectorial cooperation and integration was provided, as well as an analysis of the main drivers and barriers for IS and EE implementation in future scenarios for European process industries.
\end{abstract}

Keywords: industrial symbiosis; energy efficiency; energy-intensive industries

\section{Introduction}

Over the last few decades, the negative impacts on the environment, mainly due to increased urbanization and industrialization, as well as the intensive use of land and natural resources, have led to a growing interest in the concepts of industrial symbiosis (IS) and energy efficiency (EE), and their potentials in terms of environmental, economic, and social aspects. Energy-intensive industries (EIIs) are keen to implement measures for reducing their energy and resource consumptions. Smart management and efficient recycling of waste and water represent further important measures to improve efficiency and reduce the environmental footprint of production processes. On this subject, although case studies on IS and EE have grown in recent decades, only in recent years has this trend increased, due to the increased attention and commitment to sustainability related to high energy consumption and waste/byproduct production.

The literature discussing the changes and reinterpretations on the concept of IS was analysed in a recent review paper [1]. The number of publications on IS for the period of 1989-2019 drastically increased during those years, with an increasing attention on research activities. In this context, the concept has been evolved through its interaction with various other concepts and applications. An overview of the scientific growth of the 
IS concept and its future growth was also provided. In addition, different strategies to implement energy-based IS synergies were reviewed and discussed, including drivers, barriers, and enablers of business development from technical, economic, regulatory, and institutional perspectives [2]. The literature survey showed that energy-based IS is one of the pioneering fields seeking to reach an energy transition in the circular economy (CE) context. On the other hand, IS was outlined as an important application of the CE concept, by considering both technical and economic dimensions of this transition. This was provided in a recent study [3] that included research done worldwide that involved academic disciplines to understand the contextual development, sustainability, dynamics, facilitation tools, business models, etc.

A recent review paper provided a further overview of IS examples in the world, showing the potential for its application both in developed countries and in countries with developing economies [4]. In this review study, the process industries considered, such as the chemical industry, cement industry, paper industry, steel and iron industry, power plants, and refineries, appear most frequently in IS. However, waste and wastewater companies were also part of a large number of IS examples. In particular, both cases of IS activities already implemented and potential implementations to be developed, not only in Europe and Asia, but also in North America, Oceania, North Africa, and South America, were provided. In addition, synergies between industries and surrounding communities aim at developing significant advantages for both parties. Furthermore, concerning the e-waste industry, it is important to integrate its perspectives and engage external partners in the context of IS to include economy-wide and intersectoral cooperation. Forming a good partnership with other sectors by integrating them in the supply chain can lead to an effective e-waste management system [5].

Measurements of energy efficiency based on plant-level data in some energy-intensive sectors, such as the pulp/paper and cement industries, show that regional circumstances should be considered when seeking to improve energy efficiency [6]. On the other hand, innovative measures for improving energy efficiency are fundamental not only for reducing energy consumption, but also for achieving clean and low carbon objectives. In effect, consistent energy management, practices related to IS, the improvement of eco-efficiency, and the use of alternative fuels derived from renewable sources represent the key aspects [7]. In this context, energy-intensive sectors can reduce their environmental impacts without compromising the technical requirements in the involved processes, and can improve energy efficiency in their industry.

The present review paper derives from an analysis performed in a project devoted to the development of a blueprint strategy for human capital development through a crosssector skills alliance on energy-intensive industries (EIIs), and involving key stakeholders from the sectors of the SPIRE public-private partnership. The project aims at developing a blueprint entitled "Skills Alliance for Industrial Symbiosis: A Cross-Sectoral Blueprint for a Sustainable Process Industry (SPIRE-SAIS)" that will target ongoing and short-term satisfaction of new skill demands regarding cross-sectorial IS and EE in European process industries.

The main purpose of this review paper is to provide a comprehensive review of previous studies and activities on IS and EE in EIIs. The paper presents the current implementation of the IS and EE concepts in the European process sectors, including the transactions of material and energy flows. Although several examples of IS have been provided over the last few years, this review paper aims at providing a comprehensive review and a quantitative view of previous studies concerning the trend of IS and EE activities in European energy-intensive industrial sectors, including an in-depth analysis of their impacts.

The paper is organized as follows: Section 2 presents the methodology used; Section 3 provides some background on the concepts of IS and EE and the manners in which such concepts are supported at European level; Section 4 presents the current status of IS across the sectors involved in the pursued analysis, while Section 5 analyses the current status of 
EE developments in the same sectors. Finally, Section 6 provides a discussion and some concluding remarks.

\section{Materials and Methods}

In order to perform a comprehensive review analysis on the IS and EE in European process industries, different steps were considered. In particular, the selection and analysis of related material was carried out, by identifying, evaluating, and synthesizing the existing literature. In addition, the various aspects (i.e., IS and EE) were classified based on the different considered sectors. Results from scientific literature, official and public documents of each sector were analysed to describe the current state of IS and EE in different sectors. Starting from the eight sectors of the SPIRE (Sustainable Process Industry through Resource and Energy Efficiency) mainly involved in the SPIRE-SAIS project (i.e., steel, chemicals, minerals, non-ferrous metals, water, engineering, ceramics, and cement), in the study carried out in this review paper, the following sectors were considered: iron and steel, chemical, non-ferrous Metals, minerals, water, cement, ceramics, and waste treatment. Compared to the sectors involved in the project, engineering was marginally considered due to its cross sectorial role that is not specific in the analysed context, although it surely provides know-how which can lead to higher production capacity. On the other hand, waste treatment was included due to its significant role in some aspects of both IS and EE implementations.

The literature review was based on the assessment of the main lines of research in IS and EE included in more recent updated studies and published case studies. In order to perform this work, the most important keywords were used on the web and in academic databases such as Elsevier, Springer, IEEE, MDPI, etc. Therefore, the generic research keywords "industrial symbiosis", "energy efficiency" and "energy intensive industries/sectors" were applied for the title, abstract, and keywords of papers. In the second step, papers were selected in order to exclude those not relevant to the main topics analysed in the review work, such as IS and EE in EIIs. A further step of the work done was aimed at retrieving general information about the involved industrial sectors and production processes, the generated physical flows, and the created environmental and economic benefits, as well as drivers, barriers, and enablers of both IS and EE in EIIs. Results included research articles, review articles, conference articles, book chapters, and editorials. Nevertheless, in order to provide greater knowledge of existing case studies, not only scientific publications were used, but also papers not published in scientific journals (e.g., conference proceedings, technical reports), which were analysed to collect more information on existing cases studies. Thanks to the consolidated experience of the authors in the various topics considered, significant works and various reports providing more information on the different topics were analysed as well. In addition, the most relevant European and, in some cases, global legislation and policies were considered. Former papers were excluded by considering only some older literature documents that were very relevant to the considered contexts. This was also done for the analysed reports. Mainly articles written in English were considered by excluding papers published in other languages, and the full text of each paper was analysed.

The large number of articles analysed reflected the high scientific output produced by the research community in the last few decades on IS and EE activities in EIIs. Not only were the number of scientific articles and reports in the fields of IS and EE taken into consideration, but citations also were mainly used to identify the most important literature on these fields.

In addition, the different amount of references among the different analysed sectors was due not only to a non-homogeneous implementation of IS and EE activities across industries, but also to differences between higher implementations of IS compared to EE practices. For instance, although there was intrinsic diversity in their activities, in the main analysed sectors, their present IS activities were taken into consideration due not only to 
the high levels of generation of wastes and byproducts, but also their developed activities in integrating wastes and byproducts into production processes and across sectors.

\section{Background on Industrial Symbiosis and Energy Efficiency}

\subsection{Industrial Symbiosis}

In biology, symbiosis is defined as the "association of individuals of different species in a relationship where there is mutual benefit" [8]. By applying this concept to industry, IS "engages traditionally separate entities in a collective approach to competitive advantage involving physical exchange of materials, energy, water, and by-products" [9]. Almost 10 years ago, Lombardi and Laybourn defined IS as "a business opportunity and tool for eco innovation" [10]. In effect, the implementation of this concept aims at improving production by saving energy and resources through the cooperation among companies in byproduct or waste use [11]. IS is associated with transactions in which an organization acquires underutilized resources (including infrastructure and services) from the organization generating them, and integrates such resources into its own production process [11], resulting in mutual advantages from economic, environmental and social perspectives [12].

For a practical IS application, it is fundamental to overcome economic, technological, regulatory, and social obstacles to its development. On this subject, the knowledge and the investigation of drivers (factors that promote and facilitate the development of IS) [13] and barriers (factors that hinder the development of IS) are crucial [12]. In particular, the main drivers can be represented by diversity of industries, geographical proximity, facilitating entities and legislation, plans, and policies [4]; specifically, the need to reduce raw material and waste-disposal costs and the potential generation of revenue; and on the other hand, existing policies and legislation, such as regulatory pressure and landfill tax, represent drivers for companies in order to achieve solutions for efficient use of resources and for reduction of waste disposal.

On the other hand, barriers can be environmental, economic, technical, regulatory/legal, organizational, social, and cultural. The environmental component can be due to international and national constraints on reductions of greenhouse gases (GHG) and other types of emissions, as well as of the amount of waste sent to landfills and incinerators. Further barriers can consist of: low taxes on landfill disposals, lack of policies encouraging IS, lack of funds to promote IS, deficient regulatory frameworks, existing stringent legislation, companies' reluctance to establish synergistic relationships, lack of trust, resistance to providing data on processes and generated waste, and uncertainty related to profitability of the symbiosis network and the associated costs and risks. Concerning the economic component [14], some IS cases cannot provide economic benefits, due, for instance, to the lower price of raw materials with respect to solid byproducts produced in industrial processes and the low impact of transportation costs (e.g., low cost of transportation for discharging byproducts). Furthermore, the role of governmental policy in facilitating IS implementation is fundamental [15]. On this subject, regulations and policies can encourage or can limit IS implementation. In particular, legislation and policies should be clear, consistent, and less bureaucratic, and economic incentives can facilitate IS implementation by providing monetary support to companies. In addition, concerning social aspects, the role of facilitators is fundamental, as they provide training to employees and assist companies in creating trust and cooperative relationships. Since a relevant barrier to implementing IS consists of data transactions between industries, an industrial sector blueprint can be a solution to overcome the challenge of information transactions [16]. In addition, government investments in research and development of technological innovations can lead to new in job creation, long-term links between companies, and new synergy networks.

In the long-term, the European Union (EU) is committed to avoiding waste production, and to re-use waste as a resource in order to transform Europe into a so-called "recycling society", which, on one hand, minimizes wastes production, and, on the other hand, when wastes are generated, exploits them as a resource. Some European Commission directives, communications, and funded programs are devoted to IS. The communication entitled 
"Roadmap to a Resource Efficient Europe" aims at ensuring the sustainable management of resources based on economic growth [17]. The communication "Closing the loopAn EU action plan for the Circular Economy" underlines the importance of IS by the cooperation with EU member states' promotion [18]. The Directive 2018/851 on waste aims at improving the efficiency of waste management and encourages EU member states to implement IS [19]. In addition, the importance of IS is underlined by other directives and communications [20,21], as well as by the "Circular Economy Action Plan" [22], which is one of the main building blocks of the European Green Deal, the new agenda of Europe for a sustainable growth. The Green Deal strategy and the concept of CE concern more sustainable management of materials and resources, as well as more rational practices in waste management and recycling [23]. The main elements of this strategy are shown in Figure 1.

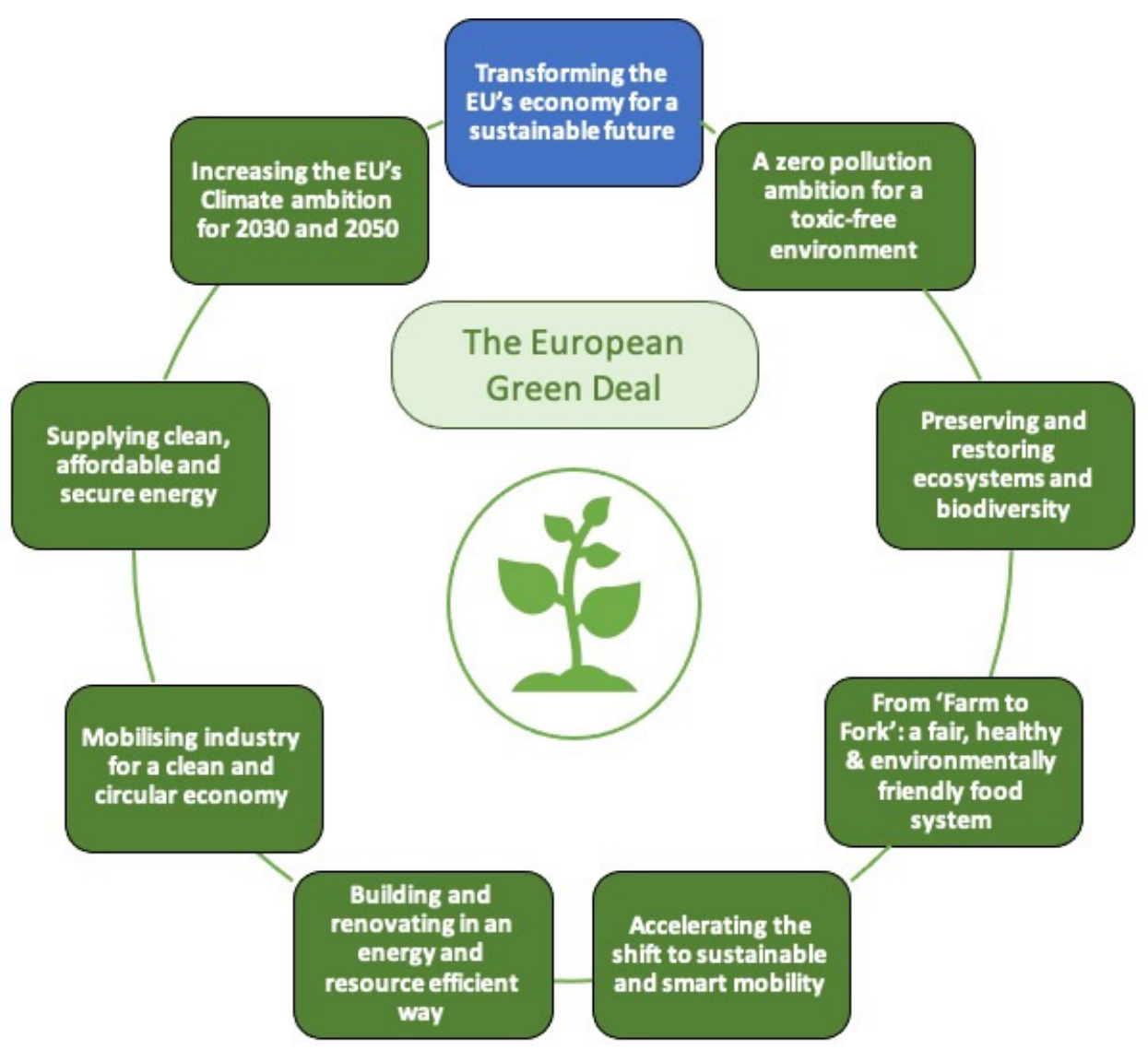

Figure 1. Elements of the European Green Deal.

The challenge for the EU is to implement CE and the Green Deal strategy, mainly focusing on achieving increased levels of critical raw-material recycling. Further priorities are deeper stakeholder involvement and increasing ecological awareness among enterprises involved in the raw-materials sector. On this subject, the previous European strategy "Europe 2020" also concerned rational resource management, according to three priorities: (1) smart growth, based on knowledge and innovation; (2) sustainable growth, based on improvements in resource efficiency and a greener and more competitive economy; and (3) inclusive growth, focused on a high-employment economy with social and territorial cohesion [24]. After the Energy Union initiative [25], the European Commission (EC) launched the European Green Deal for the EU and its citizens, foreseeing a new binding climate law to achieve a complete reduction in net emissions of greenhouse gases (GHGs) by 2050 [23]. This strategy is also an integral part of actions focused on the implementation of the 2030 Agenda and sustainable development goals of the United Nations [26], which indicated 17 such goals, aimed at preventing climate change through better natural resource 
management. In order to deliver the European Green Deal, in raw-materials management, the three aspects of sustainable development (economic, environmental, and social) must be taken into account. In particular, the mobilization of industry for a clean and CE is recommended, by increasing recovery and recycling rates in order to achieve the "zerowaste" goal [27], through the implementation of the so-called "4 Rs" [28] (i.e., Reduce, by minimizing the environmental impact; Reuse byproducts and energy, Recycle byproducts and energy from one sector to other ones; and Restore, by reducing the product's impact). In effect, around half of the total GHG emissions and most of the biodiversity loss and water stress are due to raw-material extraction and processing of materials, fuels, and food.

The Green Deal strategy and CE model aim at preserving resources within the economy when product life cycles end, allowing their sustainable reuse and creating further value. This transition requires changes in the value chain, from the product design to new business and market models [29]. This involves system change and innovation in technologies, in financial models, environmental assessment, society, and politics. On this subject, it is important to find new solutions based on IS, due to some waste materials' characteristics, such as toxicity, as well as the high costs and energy consumption of the related recycling process. In order to evaluate new IS implementations, environmental, economic, and social indicators can allow measuring of the impact of the IS, although social indicators, due to their subjectivity and complexity, are difficult to quantify [30]. However, it is crucial to define specific indicators and integrate them as a tool in the decision-making process.

\subsection{Energy Efficiency}

Nowadays, fossil fuels still dominate the world's energy consumption, and this situation is likely to persist over the next decades. According to available data (provided by Forbes), fossil fuels still provide $84 \%$ of the world's energy, with $27 \%$ provided by coal [31]. The long-term target cannot be met if there are no substantial changes to policy and technological approaches in primary energy usage. Therefore, the challenge is represented by deploying low-carbon technologies and adopting renewable energy sources to tackle GHG emissions and global warming, as well as to increase energy sustainability and economic development. The Energy Technology Perspective model for a low-carbon future was developed by the International Energy Agency [32]. The use of available technologies can potentially contribute to $38 \%$ of $\mathrm{CO}_{2}$ reduction, while carbon capture and storage and renewable energy technologies could respectively contribute to $19 \%$ and $17 \%$ of emissions reduction.

The industrial sector is one of the largest energy users in EU. For this reason, the EU introduced regulations to reduce emissions, improve EE, and encourage renewable energy [33]. The European energy efficiency targets should also be achieved by means of indicative national EE contributions. EE represents one pillar of the EU's Energy Union strategy to improve economic competitiveness and sustainability of the European economy, to reduce emissions and energy dependency, and to increase security of supply and job creation. As most of the energy consumption in the EU depends on non-renewable resources, measures promoting EE can help to reduce imports of fossil fuels and, consequently, to enable energy security in a cost-effective manner. By applying important actions in EE, significant levels of macroeconomic impacts can be achieved, with positive effects on gross domestic product (GDP) and employment [34]. Accordingly, the EU energy policy aims at achieving EE from a growth perspective. On this subject, the EU regulatory framework and policies include the recent 2030 Climate and Energy Policy, with $40 \%$ reduction of GHG emissions to reach a competitive low-carbon economy in 2050 [35]. In addition, the EU aims at reducing GHG emissions by 80-95\% (compared to 1990 levels) by 2050, and the Energy Roadmap issued by the European Commission aims at making the energy system compatible with this target for GHG reductions without neglecting increase of competitiveness and security of supply [36]. 
In the last few decades, several EU policies and regulations have been introduced to improve energy efficiency and encourage renewable energy. They paved the way to introduce the new growth strategy, the European Green Deal for the EU and its citizens [23]. In particular, the EU's 2020 strategy for smart, sustainable, and inclusive growth is based on climate and energy efficiency [24], as EE represents a cost-effective way to improve competitiveness and to contribute to the energy and climate goals. In particular, the so-called "20-20-20" targets concern: a 20\% cut in GHG emissions compared to 1990 levels; producing $20 \%$ of EU energy consumption through renewable resources; and a $20 \%$ improvement in EE of the EU's primary energy consumption [37]. The EU 20\% energysaving target for 2020 was first launched by the Commission in the 2005 Green Paper [38] and by the Action Plan for Energy Efficiency in 2006 [39], followed by the Energy End-Use Efficiency and Energy Services Directive (ESD) [40]. Due to the slow implementation of EE actions by EU member states to meet the 2020 target, a new directive was proposed in 2011, and the Energy Efficiency Directive (EED) (2012/27/EU) was adopted in 2012 [33] to revoke the previous Energy Services Directive, and included: legal obligations for establishing energy-saving schemes in EU member states; provisions on the setting of EE targets, general EE policies, energy audits, combined heat and power, management systems for enterprises, consumer behavior, etc. The EU member states in the National Energy Efficiency Action Plans (NEEAP) must quantify the national measures to implement significant EE improvements and energy savings in all sectors and in all stages of the energy chain.

According to the European Green Deal [23], EIIs, such as steel, chemical, and cement manufacturing, play a key role in the European economy, as they supply several key value chains. For this reason, it is fundamental to decarbonize and modernize this sector, and EIIs show their commitment to this direction by applying new technologies that allow EE improvements. In order to improve $\mathrm{EE}$, different measures can be implemented. On one hand, "soft" measures include good management [41], education, and behavior changes; on the other hand, "hard" measures include investments in EE, such as upgrades or new technology installations.

Among EIIs, it is expected that by 2050, the iron/steel and chemical sectors will increase their energy consumptions, due to an increase in steel production [42]. The energy consumption from 2011 to 2030 will increase due to the limitation of applications of emerging EE technologies in steelmaking [42]. However, due to the commercialization of breakthrough technologies from 2030 to 2040, the energy consumption trend will flatten [43]. Concerning non-ferrous metals, production will decrease due to a lack of new EU investment in production capacity and expansion of production outside the EU. In addition, this trend will be supported by the production increase of secondary metal through improved recycling and recovering useful scrap metal. Finally, production in the non-metallic mineral sector will remain moderately flat through 2050, while there will be slight declines in lime and ceramics, stable production of glass, and a slight increase in cement production [42]. Being one of the largest energy consumers in the EU, this industry needs to achieve the EE target through further investments. For instance, in the European ceramic industry, energy represents one of the highest production costs. In addition, energy cost disparities across EU member states and plants are the main issues in achieving the competitiveness of EIIs in Europe.

\section{Industrial Symbiosis across Sectors}

The development of low-carbon technologies and the use of low-carbon energy at competitive prices as well as effective policy measures can lead the European EIIs to low-carbon industrial productions and to be competitive in internal and global markets. In addition, reuse of waste, byproducts, water and energy from a production process as inputs of other traditionally available processes, represents an opportunity to ecological innovation, lower production costs and environmental and social benefits for EIIs. This 
transition can lead to higher skills, more and different jobs and open up new markets through synergies among sectors, according to the CE and IS concepts.

In the following subsection, the trends and activities developed on the topic of Industrial symbiosis within the main sectors involved in the pursued analysis are presented.

\subsection{Iron and Steel Sector}

The steel sector is strongly interested in the transition to low-carbon technologies and affordable low-carbon energy, being a strong consumer of both carbon and energy [44]. According to the International Energy Agency, the iron and steel industry accounts for approximately $4-5 \%$ of total world $\mathrm{CO}_{2}$ emissions [45]. In $2019,27.7 \%$ of the crude steel production [46] was derived from the melting of steel scrap, which means that the concept of circularity is intrinsic to the steel sector and to the nature of steel as an endlessly recyclable material. Nonetheless, the steel industry targets significant improvements [47] compared to the recent achievements in waste energy, waste, and byproduct uses [48,49]. In this regard, the current IS implementation involves transactions using byproducts and energy between the steel sector and the other sectors. Some residues coming from production processes are internally recycled, while some of them can be used by other sectors. For instance, BTX (benzene, toluene, and xylene) are used in plastic production, tar and naphthalene in the aluminium industry, plastics, and paints. On the other hand, iron oxides and slags can be used in Portland cement production; and zinc oxides, contained in the dusts resulting from the electric arc furnace (EAF) process, can be used as a raw material in the Waelz process [50].

For implementing IS, materials should lead to a final product holding the same properties as the one produced by exploiting virgin primary raw materials [51]. The selected residual materials contribute to the reduction of landfilled materials and rawmaterial consumption [52]. In addition, the use of secondary materials increases their economic potential (e.g., high economic potential for one material can increase the use of materials with lower economic potential).

Iron and steel slags are the main byproducts produced in the largest quantities in steel processes [50]. They mainly contain silica, calcium oxide, magnesium oxide, aluminium and iron oxides, and in refining processes they remove impurities, protect the liquid metal, and maintain the internal temperature in furnaces. Steelmaking slags, such as basic oxygen furnace (BOF) slag, EAF slag, and ladle furnace (LF) slag, are recovered over $80 \%$ [53], while blast furnace (BF) slag is recovered at nearly $100 \%$.

Figure 2 provides some pictures of slags coming from the electric and integrated steelmaking routes. Figure 3 provides an example of how EAF slag is handled and preprocessed in the electric steelmaking route.

It is important to know the slags' composition, their volume instability, and their leaching behavior [54] for their reuse and/or inert disposal [55]. In particular, BF slag is mainly reused in the cement industry, while it also can be potentially used as foundation material for road and railway construction, lightweight marine embankments, water treatment, and glass manufacturing. On the other hand, BOF slag is often landfilled, but can be used as fertilizer, concrete aggregate, and road paving. Furthermore, metals such as aluminium (Al), chromium (Cr), and vanadium (V) can be recovered by slag bioleaching [56], and harmful elements such as $\mathrm{Cr}$ (VI) ions (hexavalent chromium) [57], Cd(II), and Mn(II) [58] can be removed from aqueous solutions through the slag applications. Recently, EAF steel slags were studied, with promising results, by developing a five-step process [59]: (1) removal of iron scrap from slag in dry, low-intensity conditions; (2) reduction of the particle size by crushing/grinding; (3) activation of the slag by co-grinding with alkaline reagents; (4) formation of soluble phases by roasting at $400-800{ }^{\circ} \mathrm{C}$; and (5) leaching of valuable metals. Both BF and steel slags can be used for heat recovery by different methods $[60,61]$, and as energy-storage material in thermal energy storage systems [62], while EAF slag can be used in ceramic tile production and in biomedical applications, such as bone replacement, and dental and orthopedic applications [63]. 


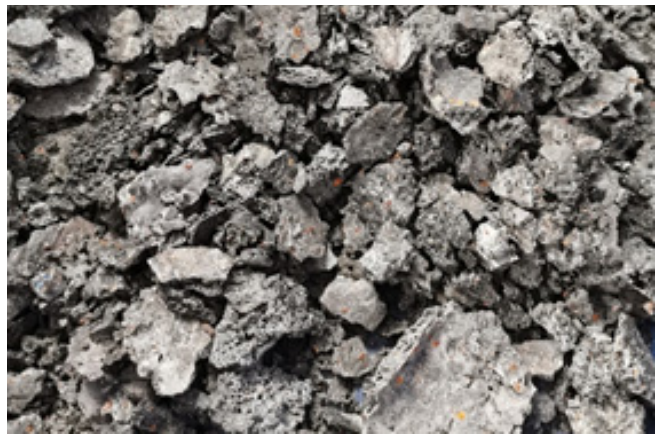

(a)

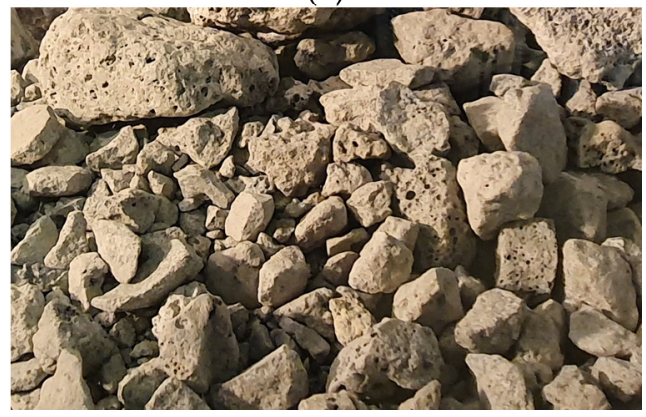

(c)

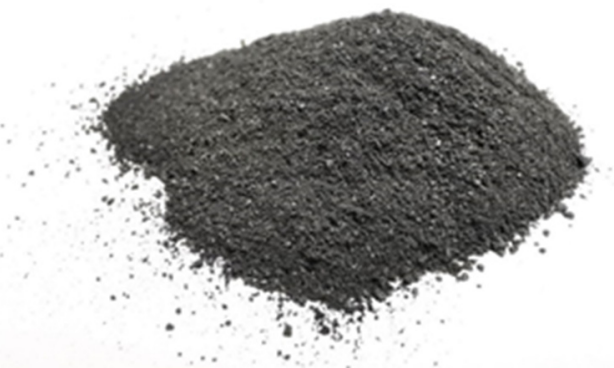

(b)

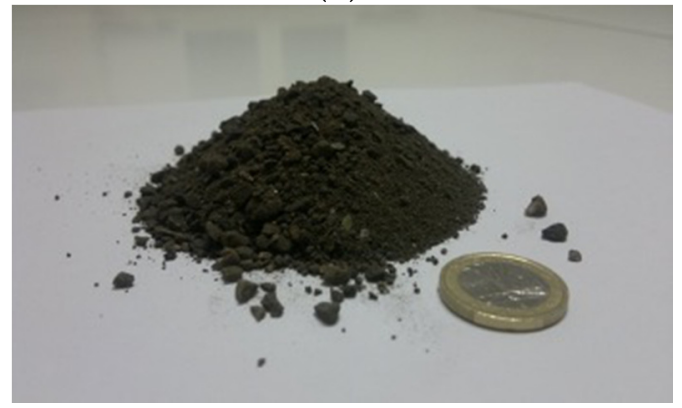

(d)

Figure 2. Examples of slag from the steelmaking cycle: (a) EAF slag with metal traces before magnetic separation; (b) EAF slag demetallized and grinded; (c) BF slag; (d) milled BOF slag.

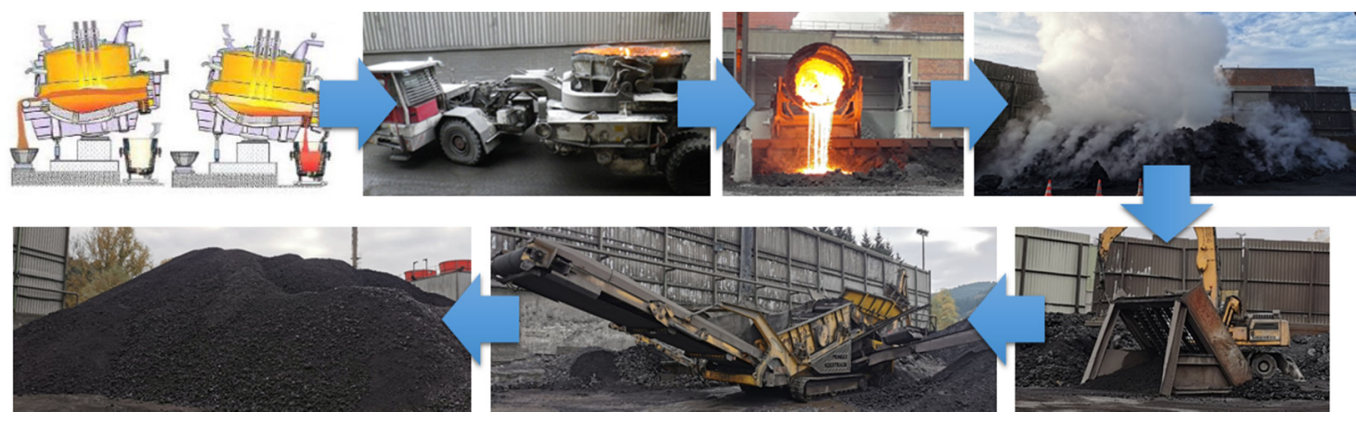

Figure 3. The EAF slag-handling process: tapping, cooling, magnetic separation, and grinding (Courtesy of Sidenor I+D).

Slags and other byproducts are generally reused in cement production. In particular, as stated above, BF slag is fast-cooled by water quenching, resulting in a glassy and granular material used for Portland cement production.

Ground granulated BF slag has significant properties (e.g., a compressive strength similar to the reference mortar) making it suitable as cement in concrete [64]. The application of dry granulation can reduce the content of harmful elements (e.g., $\mathrm{H}_{2} \mathrm{~S}$ and heavy metals), and insoluble chemical activators can be used to improve the hydraulic activity of slag-blended Portland cement. Furthermore, BOF slag can be reused by improving its hydraulic properties, through the reduction of iron oxides' iron content [65]. In addition, other byproducts originating from different sectors (e.g., steel fiber, asphalt, slag, asbestos, lead, dry sludge, wet sludge, fly ash, bagasse ash, red mud, plastic, glass, etc.) were tested to be used in concrete preparation [66].

Iron and steelmaking byproducts can replace natural aggregates in road construction $[67,68]$. For instance, the combination of foundry sands, EAF slags, and bottom ash from municipal solid waste incineration (MSWI) in five different proportions can be used for road construction [69]. Furthermore, steel slags were studied to be included in hot mix asphalt [70], and an EAF slag in the asphalt mixture was reinforced by aramid fiber [71]. 
Steel slags can be also applied for soil amendment, particularly in acidic soils, where they can increase $\mathrm{pH}$ and improve the physical properties of soft soils [72]. On the other hand, in alkaline sodic soils, BOF slag can reduce the exchangeable sodium concentration in saline sodic soil, resulting in yield improvement [73] and economic advantages [74]. Furthermore, steel slags were successful used for repairing coral reefs [75], building artificial reefs, and reducing $\mathrm{H}_{2} \mathrm{~S}$ and metalloids in marine environments [76]. However, a crucial aspect of the soil amendment through slags is represented by the content of heavy metals. In this regard, converter slag can mitigate arsenic uptake by rice [77], while iron materials coming from the casting industry can immobilize the arsenic in flooded soil [78].

Dusts and sludges are iron and steelmaking byproducts that, after being removed from process gases, can be recycled both internally [63] and externally to other sectors, such as in Portland cement production. BF flue dust can replace the traditional fuel and raw materials in cement production [79], through magnetic separation that is able to remove its iron content. In addition, the combination of BOF slag as a coarse aggregate and the BF dust as a fine aggregate were tested in asphalt hot mixes for pavements [80]. Sludge can be internally recycled as raw material for zinc ingots, used for producing wire rod in the galvanising process [81]. In addition, zinc can be recovered from the pre-treatment of coated steel scrap [82], and selective leaching tests can be used to recover pure zinc compounds or metallic zinc from EAF secondary steelmaking byproducts [83]. Furthermore, the high-zinc fraction from BF sludge can be incorporated in self-reducing cold-bonded briquettes and pellets [84].

Fly ashes can be used for producing cement and concrete, fly ash bricks, and glassceramic products [85], as well as for improving soil quality and as a soil fertilizer, due to their high concentrations of $\mathrm{K}, \mathrm{Na}, \mathrm{Zn}, \mathrm{Fe}, \mathrm{Ca}$, and $\mathrm{Mg}$.

Mill-scale coming from continuous casting and rolling mill processes can be re-used in pellet and briquette production for raw material in steelworks, for producing magnets, and also as bipolar plates, a component of proton-exchange membrane fuel cells [86].

Refractory materials can be internally recycled as slag formers or conditioners, roadbed material, slag conditioners, raw materials in the mixtures for new refractories to be used for additions to monolithic refractories or for concretes [87], and for glass and cement [88], paving the way to a CE and IS approach [89].

Iron- and steelmaking gases that originated from a coke oven, $\mathrm{BF}$, or $\mathrm{BOF}$, after cleaning, can be reused to produce steam and electricity, resulting in $60-100 \%$ of the plant's electricity requirements [90]. For instance, hydrogen contained in coke oven gas can produce power in steelworks, and ammonium sulphate can be used as fertiliser. Moreover, such gases can be valorized through hydrogen-intensified methane and methanol synthesis processes, the environmental sustainability of which can be emphasized through low-C or green hydrogen production technologies [91]. In addition, thermal energy losses can be recovered and used (e.g., heating, electricity production) both internally and by external companies (e.g., glass, ceramic, oil refineries, and incinerators) with significant reductions in fossil-fuel use.

According to the IS concept, residues from different sectors can be used in the steel sector as secondary materials. For instance, carbon-bearing materials, such as biomass, residues from food companies, and plastic and rubber wastes, which are usually landfilled, can replace fossil materials such as coal and natural gas. In particular, biomass can reduce fossil-based $\mathrm{CO}_{2}$ emissions [92] as a reducing agent [93] and as a substitute in pulverized coal injection. In addition, in the EAF route, fossil fuels can be replaced by biocharagglomerates [94], and carbon dioxide and plastics can be used as fuels/chemicals in high-temperature iron and steelmaking [95]. The injection of carbon and charge carbon in an EAF using renewable biocarbon can reduce more than 50\% of GHG emissions [96], and by replacing fossil carbon sources with waste plastics, $\mathrm{CO}_{2}$ emissions can be reduced by about 30\% [97].

Among many current or pending IS activities that are relevant in Europe, two projects have been reported as positive examples. In the first, the hypothesis of industrial symbiosis 
in the Taranto area includes the ArcelorMittal Italia (AMI) steel plant in the center of a network of multisectorial synergies. The objective was to identify and optimize practical solutions, to implement the concepts of IS in a concrete way while promoting cross-sectorial dialogue and technology transfer, and presenting the steelworks as a flywheel for the economical and sustainable growth of the territory [98]. The second example is represented by an ongoing EU funded project (Creation of new value chain relations through novel approaches facilitating long-term industrial symbiosis-Coralis; GA N. 958337), which aims to implement different demo cases of IS systems in different European regions. The steel and metal sectors are represented by an IS system located in the north of Italy (Brescia district), where two steel factories, an aluminium producer, and a foundry cooperate in a mutual materials exchange in order to reduce the landfill of materials and save virgin raw materials.

\subsection{Chemical Sector}

The chemical sector represents one of largest European manufacturing sectors, playing a crucial role in supplying innovative materials and technological solutions to support the competitiveness of European industries [99]. Currently, this sector is affected by rapid structural changes to maintain its market shares, although the increasing role of other countries and the costs are rising. The chemical industries play a key role in the entire EU economy [99]. In particular, they:

1. Represent around 7.5\% of EU manufacturing by turnover;

2. Had sales in 2018 amounting to EUR 565 billion, representing about $17 \%$ of global chemical sales;

3. Provided 1.2 million direct highly-skilled jobs in 2015;

4. Created around 3.6 million indirect jobs and supported around 19 million jobs across all value supply chains;

5. Had a labor productivity $77 \%$ higher than the manufacturing average; and

6. Generated a trade surplus in 2018 of EUR 45 billion.

The chemical sector represents the heart of the EU manufacturing industry, as $56 \%$ of EU chemicals sold to downstream users are devoted to other sectors such as agriculture and services sectors. Innovative and new industrial cooperation activities between the chemical and other sectors are ongoing and involve material and energy flows, and this represents a significant aspect for implementing IS and CE activities. In addition, the chemical industries are effective drivers of resource and energy efficiency.

The chemical industries cover different sectors, including oil and gas (refineries) and consumer goods companies (representing sludge and organic residual treatment, and recovery of valuable materials). These two subsectors are analyzed in deeper detail in the following subsections due to their significance and representativeness within the entire sector.

\subsubsection{The Refinery Industry}

Over the last few years, efforts to increase exploration and production of oil and gas that also include a cost decrease has led to the stability of reserves worldwide. In particular, in 2019 the world's oil refinery capacity reached over 101 million barrels per day, and globally in the last 50 years, it has more than doubled [100]. The largest refining region in the world is Asia ( $25 \%$ of the total), followed by North America and Europe (around 20\% for each one). The main refining countries in the world are the United States, China, Russia, and Japan. The European market has shown a growing demand for petrochemicals, kerosene, and diesel, but a declining demand for gasoline, light heating oil and heavy fuel oil. In addition, the market is characterised by high competitiveness due to increasing capacity in the Middle East and in Asian countries. European refineries are still not producing the mix demanded by EU consumers due to their technical design, and they are not able to satisfy the current demand for diesel, while producing gasoline in excess. 
The classification of refineries is based on the number of available processes for the transformation into petroleum products. On one hand, simple refineries distil crude oil into a limited range of yield and products. They are referred to as topping or hydroskimming plants; topping is the most basic distillation process, while hydroskimming concerns distillation in the presence of hydrogen. On the other hand, complex refineries combine interrelated processes to produce a broader range of refined products. They generally use thermal and catalytic cracking, enabling deeper conversion of the crude oil feedstock into higher yields of more valuable and marketable products. To provide some examples, the Kalundborg Symbiosis [101] is an industrial park that includes four facilities (i.e., a power plant, an oil refinery, a plaster-board manufacturing plant, and a biotechnology production facility), with the participation of the local municipality. Within the industrial facilities, there is a symbiotic transaction of material and energy flows, resulting in reduction of resource consumption, emissions, and waste. In particular, significant achievements in IS at Kalundborg can be summarised as follows:

- Significant reductions in energy consumption, as well as in coal, oil, and water use;

- Reduction of environmental impacts by reducing $\mathrm{SO}_{2}$ and $\mathrm{CO}_{2}$ emissions and improving the quality of effluent water; and

- Conversion of traditional waste products (e.g., fly ash, sulphur, biological sludge, and gypsum) into raw materials.

Another significant example is the Taranto industrial district [102], which is characterised by various EIIs, such as steelworks, an oil refinery, cement industry, and power stations (see Figure 4). The results of a study funded by the Caripuglia Foundation showed that the full implementation of IS in that area is feasible only through the adoption of the industrial ecology paradigm in a sustainable way, taking into account the economic, environmental, and social aspects. A full involvement and coordination of the industries of the district in IS implementation could effectively make the Taranto industrial system more environmentally sustainable and competitive.

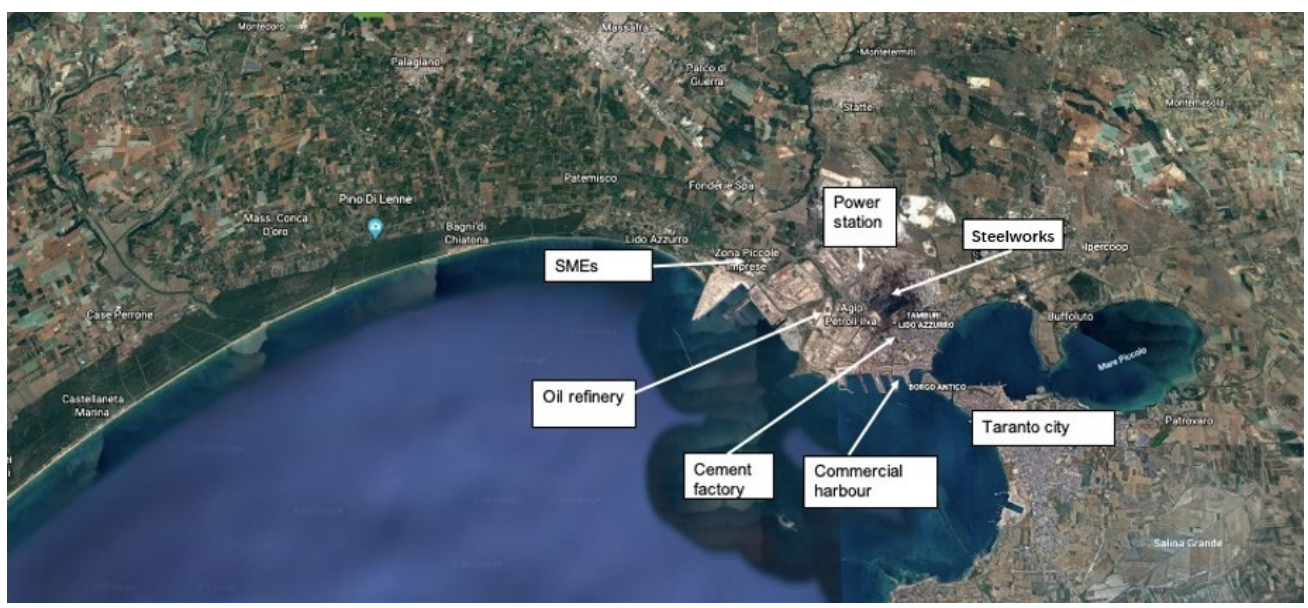

Figure 4. The Taranto industrial district (picture retrieved from Google Maps).

The Grangemouth Development Group (GDG) [103] is an organization formed in 1992 that includes the major companies in Grangemouth, Scotland, and the Local Enterprise Council, Forth Ports, and Falkirk District Council. It aims at improving local chemical industry competitiveness and creating further jobs. The "snowball effect" characterized the company culture towards further cooperation and outsourcing at a time of increasing competitiveness and efficiency of chemical use, and by recovering the chemical at the end of its lifecycle.

In another example of IS implementation, Guayama, Puerto Rico, hosts different industries: a fossil-fuel power-generation plant, pharmaceutical plants, an oil refinery, and various light manufacturers [104]. In particular, the new AES coal-fired power plant uses 
reclaimed water from a public wastewater treatment plant for cooling, and provides steam to the oil refinery. Additional steam and wastewater exchanges can be provided between the pharmaceutical plants, refinery, and power plant. In addition, reuse of the coal ash for stabilizing some liquid wastes could be a promising use. These activities provided a significant public environmental benefit. In particular, a $99.5 \%$ reduction in $\mathrm{SO}_{2}$ emissions, due to steam generation for Chevron Phillips, was achieved, and AES avoided extracting 4 million gallons per day of scarce freshwater by using treated effluent coming from the wastewater treatment plant.

The Campbell Industrial Park [105] is the largest industrial park in the state of Hawaii, USA, where the core group is called the Campbell Industrial Symbiosis, anchored by the only coal-fired plant on Oahu, owned by AES Corporation and producing around 180 MW. It includes the oil-fired Kalaeloa cogeneration plant (210 MW) and two large oil refineries. These oil refineries operate small ( $~ 9$ MW) cogeneration plants and steam boilers, and other industries. By applying a life-cycle assessment to the Campbell Industrial Symbiosis, positive environmental benefits for all impacted categories and all exchanges have been detected.

Figure 5 shows a total of 11 companies that exchange nine different materials.

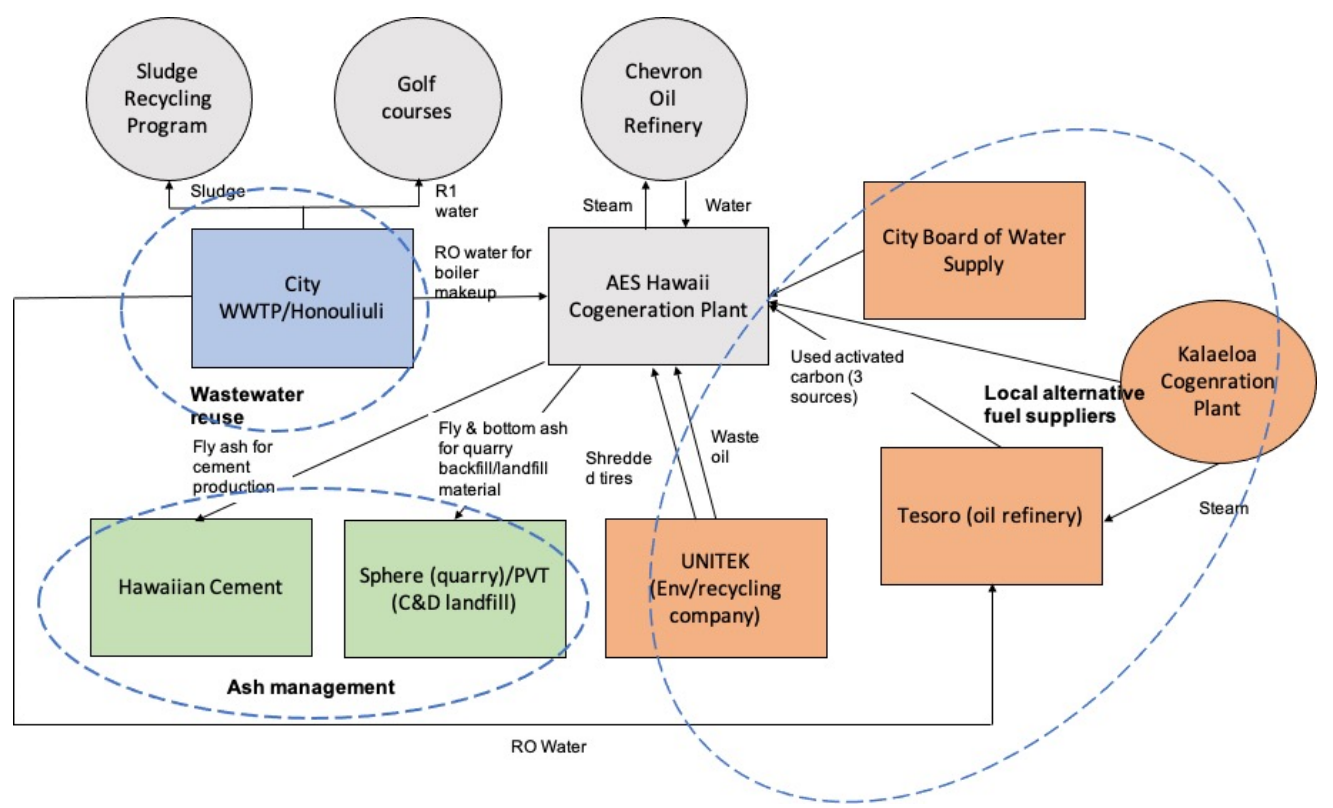

Figure 5. The existing symbiotic network around AES Hawaii [105].

Finally, the Ulsan/Mipo Onsan industrial complex [106] is the largest industrial area of petro-chemicals, automobiles, shipbuilding, and non-ferrous metals in Korea. Over the past few decades, a few companies in Ulsan have been interested in trading the excess materials from the production line for economic purposes, with an increasing number of companies participating. Recovery of previously discarded waste or byproducts and recycling of wasted heat and water have led to designing and implementing IS in a sustainable way, both economically and environmentally. The current evolution of IS in Ulsan industrial parks can promote sustainable development at the regional scale.

\subsubsection{Consumer Goods Companies}

The consumer goods industry includes multinational consumer goods companies such as Samsung, Apple, and Sony, as well as giants such as Nestlé, Procter \& Gamble, and Unilever [107]. Although the European consumer goods industry includes some global players, such as the ones mentioned above and other representatives of the genre (e.g., Henkel, Adidas, Dr. Oetker, and Maxingvest), it is often characterised by small to mediumsize enterprises (SMEs). In particular, the average consumer goods company achieves 
an annual turnover of EUR 28 million and approximately 110 employees. However, differences between the individual branches exist. For instance, a large number of textile or publishing companies had a turnover of less than EUR 20 million per year and employ fewer than 100 people on average [108]. In the last few years, these companies have employed about one million people and produced and sold durable and non-durable goods worth nearly EUR 300 billion. The demand for "final consumer goods" actually determines to a large extent the demand for "intermediate consumer goods", and the interaction, even multinational, of a network of companies [108]. Using the logic of global efficiency, in the economic strategies of production of these companies, innovative models of IS and circular business have evolved. This is mainly due to the large supply networks that develop upstream of the consumer goods companies [109]. The operational strategies developed include:

- IS: transaction of services, public services between industries to improve resource efficiency (i.e., to develop different products starting from common elements, the latter supplied by a single company capable of mass production and, therefore, minimizing the price for each single supply).

- Closed loop recycling and downcycling: use of recycled products as raw materials for the manufacture of new products or for their transformation into lowerquality products.

- Centralized collection services: a service for the cataloged collection and differentiation of waste products, old products, or those used by different companies.

- Recycling: transformation of secondary, old, or used products of one or more companies into new goods produced by a third company that is therefore able to sell these goods at a competitive price.

- Product service system: offering a solution associated with placing the good on the market, leading to a marketable set of products and services provided by the same company or by associated companies.

- Modularity and lock-in: designing an asset made up of smaller parts, each built by different industries. Each part can be produced, used, and replaced independently, effectively extending the average life of the asset. This effectively encourages consumers to continue using a specific product or service derived from one or a group of companies.

- Local circuit: the entire production chain is located and organized in the same district in a grouping of industries, minimizing energy and supply times.

- Customization: opportunities for managing and using customer feedback between multiple companies, allowing both the personalization of the individual product and the possible offer of other associated goods (e.g., toothpaste/toothbrush, shampoo/brush, shoe/sportswear). The data can then be shared within companies for more efficient offer management.

The various strategies mentioned above have already begun to be widely implemented in recent years by large multinational companies such as Nespresso, M\&S Schwopping, and Nike, with various initiatives including "Nike Reuse-A-Shoe" and the "Glocal di Ecover". These initiatives are valid examples of IS activities, communication, exchange, and common intentions shared between a group of companies, aimed at creating products designed to be competitive, customized, and reusable, and with a low environmental impact [110].

\subsection{Non-Ferrous Metals Sector}

Over the last 30 years, in the European non-ferrous metals industry, a high level of electrification and recycling have been implemented, leading to significant improvement in achieving its sustainability. This makes it strongly involved in contributing to the objectives of the EU 2050 climate-neutral strategy, synthesized in the report: "Metals for a climate neutral Europe-a 2050 Blueprint", prepared by the Institute for European Studies (IES) for Eurometaux, the European non-ferrous metals association [111]. In this report, the 
base metals, such as silicon, ferro-alloys, precious metals, specialty metals and rare earth elements (REE), are considered and classified, as follows:

- Base metals: aluminium, copper, lead, nickel, tin, zinc (+ silicon and ferro-alloys);

- Precious metals: gold, silver, platinum, palladium, ruthenium, osmium, iridium, and rhodium;

- Specialty metals: cobalt, germanium, gallium, indium, selenium, antimony, magnesium, molybdenum, cadmium, beryllium, bismuth, chromium, niobium, vanadium, hafnium, lithium, manganese, rhenium, tantalum, tellurium, titanium, and tungsten;

- REEs: neodymium, dysprosium, scandium, cerium, erbium, europium, gadolinium, holmium, lutetium, ytterbium, thulium, lanthanum, praseodymium, samarium, terbium, and yttrium.

Non-ferrous metals are essential in infrastructure, such as buildings, transport, and electronics. They are also present in strategic sectors, such as defence and telecommunications, as well as in other economic sectors, such as food, jewellery, etc. They are particularly essential and irreplaceable in the production of low-carbon technologies. In Europe this sector is worth EUR 120 billion, and employs around 500,000 people directly and more than 2 million people indirectly. There are 931 European facilities, including mining (54), primary and secondary production of metals (464), and further transformation (413). Metal production is present in most EU member states, in particular in Italy (179 facilities), Germany (147 facilities), Spain (116 facilities), France (82 facilities), the United Kingdom (53 facilities), and Poland (51 facilities) [111]. The total European production of non-ferrous metals is around $47 \mathrm{Mt} \mathrm{[112].}$

All metals are basically produced in two ways: the conversion of ore to metal and the recycling of metal scrap. Among non-ferrous metals, aluminium is the most used by volume and the second most widely used metal after iron in the EU and globally, while copper is the second-largest base metal sector in the EU. Due to the scarce presence of ore resources in Europe, the extractive industry (mining) of non-ferrous metals represents a small sector. Consequently, Europe imports around $80 \%$ of its needs from other continents, as non-ferrous metals have a strategic importance for Europe, in particular, for large number of industrial sectors, ranging from essential to high-technology and sensitive sectors, in which non-ferrous metals are indispensable.

Non-ferrous metals are crucial for decarbonization, as the transition to a carbon neutral Europe can be achieved only with sufficient amounts of non-ferrous metals. They are used in all technological solutions for decarbonization (e.g., battery and fuel cells for electrical-based transport systems, solar photo-voltaic panels and wind turbines for producing renewable energy, battery storage and smart grids, and 100\% recyclable packaging). Consequently, due to low-carbon transition, the Organisation for Economic Cooperation and Development (OECD) estimates that total consumption will increase from $7 \mathrm{Gt}$ to $19 \mathrm{Gt}$ per year by 2060 [113]. Due to the increase of decarbonization technologies, higher quantities of aluminium, cobalt, copper, lead, zinc, nickel, and lithium will be consumed.

The non-ferrous metals industry has always adopted the IS concept with other sectors. As raw materials are not available, recycling has been always a must. On this subject, the European metal-recycling industry is a world leader, with a $24 \%$ market share [111]. Innovative solutions have been developed to recover metals from waste and byproducts from the production process in an economic and technical sustainable way. In addition, residues from metal production are used as additives in roads, construction, or other markets [112]. The European non-ferrous metals industry is an ecosystem of mining, smelting, transformation, refining, and recycling operations across the continent. This sector is an ecosystem in nature. In practice, metal ores consist of various elements commonly coexisting. Consequently, there is a strong interlinkage between different metals during the smelting, refining, and recycling processes. When a primary metal is produced, other metals can be separated as byproducts that can be used as raw materials for other productions. At the same time, metals from other byproducts are commonly recovered and recycled, providing secondary raw materials. For this reason, this sector presents a high 
degree of electrification, circularity, and emission reduction, and it is committed to being a real pioneer in reducing GHG emissions to zero by 2050.

The vision for the future of the European non-ferrous metal industry is based on two main pillars:

1. Increasing importance of the non-ferrous metal sector for a carbon-neutral and competitive European industry; and

2. Its intrinsic tendency to recycle and recover metals from byproducts.

These two pillars can allow the building of a new industrial system based on the IS approach, with high environmental performance, resource efficiency, and innovation, aiming to reduce the $\mathrm{CO}_{2}$ footprint of European primary production, but also to reduce the import dependency and improve security of the supply of strategic metals. Furthermore, the technological innovation is crucial to realizing a better life-cycle understanding of materials, tracing and controlling materials, improving process flexibility and EE, and facilitating the transition to renewable energy [114].

Within the non-ferrous metal sector, the aluminium industry shows a particular importance. European Aluminium represents the entire value chain of the European aluminium sector [115]. The main actions of upcoming strategies will be based on the protection of the competitiveness of European aluminium producers and industrial energy consumers. In addition, the main goal Europe should be focused on is how to reinforce its strategic autonomy in global value chains, preserve existing industrial assets, and restore production in Europe. This will significantly reduce the current carbon-intensive imports. In this context, European companies need to take part in a framework that enables them to become more energy-efficient, competitive, circular, and sustainable in order to deliver and invest in climate neutrality and to act in a free and fair trade environment.

According to the new Circular Economy Action Plan [22], European Aluminium's policy aims at ensuring circular material handling along the entire value chain, starting with the product design, as well as at creating appropriate incentives for circular solutions and products, to boost investment in collection and sorting and promote innovation of production processes [116]. The Vision 2050 for the aluminium industry focuses on recycling and policy recommendations for achieving full circularity. Aluminium can be recycled multiple times without losing its original properties, which include lightness, conductivity, formability, durability, impermeability, and multiple recyclability. This material in Europe can reach recycling rates of over $90 \%$ in the automotive and building sectors, and $75 \%$ for aluminium cans. These results have been achieved thanks to developed collection systems, in particular, for vehicles reaching their end-of-life, building scrap and used beverage cans; high scrap sorting rates; low losses when aluminium is re-melted into recycled metal; and a high-quality end product that can be used in high-value applications. Recycling aluminium in Europe can lead to avoiding relevant $\mathrm{CO}_{2}$ emissions, due to the reduction of carbon-intensive aluminium imports. Furthermore, this recycling process requires only $5 \%$ of the energy needed for producing the primary metal, resulting in 0.5 tonne $\mathrm{CO}_{2} \mathrm{eq} /$ tonne recycled aluminium (gate to gate). In order to maximise aluminium recycling rates and to keep the material in active use, it is important to ensure collection and efficient recycling in Europe of all end-of-life aluminium products. Support policies and cooperating with the academic world can lead to coordinated measures along the value chain, influence market demand for circular solutions and consumer awareness, make investments economically viable, and the development of business models required to underpin them.

\subsection{The Mineral Sector}

The New Circular Economy Action Plan was published in March 2020 [117]. It provides a holistic strategy for how to tackle and address the challenge ahead. In this context, some actions reported in the CEAP concern directions will have an impact on the minerals sector, as follows:

- Launch of an industry-led IS reporting and certification system for 2022;

- Strategy for a sustainable built rnvironment (2021); and 
- Regulatory framework for the certification of carbon removals (2023).

The mineral sector is committed to apply new innovative technologies along the industrial minerals value chain, including developments in extraction, beneficiation, drying, calcining, and waste recycling. These will allow the EU minerals industry to decrease the use of natural resources, which consequently will lead to sustainable productions with less waste and lower environmental impacts. Multiple mineral solutions illustrate the viability of this recovery and the sectors that can benefit from these innovations (e.g., bentonite for valorizing tailing wastes and clean processed water). In particular, innovative projects have been developed to achieve more sustainable business models, going from the extraction and processing of the minerals, through delivering products to the value chains, to recovering of the land after its use $[118,119]$. The mineral industry can provide solutions to address social challenges of energy transition, $\mathrm{CO}_{2}$ reduction, and resource recovery. In addition, waste valorization for critical raw material recovery can be addressed through a holistic sustainable approach. Furthermore, past historical waste can serve as sources to supply the demand for battery raw materials or for energy-transition raw materials. For this reason, the industrial minerals sector, according to the IS concept, can address societal challenges to such cross-sectorial cooperation to reduce the $\mathrm{CO}_{2}$ and resource footprint. Finally, data and information availability on secondary materials, as well as a harmonised legislative framework within the EU, are crucial for the large-scale deployment of recovery practices involving this sector.

\subsection{The Water Sector}

About $44 \%$ of total water abstraction in Europe is used for agriculture, $40 \%$ for industry and energy production (cooling in power plants), and 15\% for public water supply [120]. Water is mainly consumed in irrigation, urban, and manufacturing sectors. Industrial water consumption is used for cooling purposes in energy production, while the other half is mainly used for process and manufacturing industries in the chemical, food and feed, paper and pulp, oil and gas, textile, metals, mineral, and mining sectors [121].

Water is the most important resource in the world, and its consumption is continuously growing due to its intensive use in industrial processes and agriculture, as well as in the urban context. However, over the last few years, new initiatives were launched. For instance, the new European consortium NextGen represents a new challenge in the water sector that, according to the principles of $\mathrm{CE}$ and through technological innovations, aims at preserving natural capital, optimising resources, and improving system efficiency [122]. NextGen is seeking to achieve sustainability and bring in new market dynamics throughout the water cycle. The goal of the consortium consists of high-performance innovation, business models, and governance conditions to mainstream these solutions, with 10 largescale demonstrations in eight different EU countries. The new approach is developed at six sites for water supply infrastructures and solutions in urban or rural areas. This includes a wide range of water-embedded resources: water itself (reuse at multiple scales supported by nature-based storage, optimal management strategies, advanced treatment technologies, engineered ecosystems, and compact/mobile/scalable systems); energy (combined waterenergy management, treatment plants as energy factories, and water-enabled heat transfer, storage, and recovery for allied industries and commercial sectors) and materials (nutrient mining and reuse, manufacturing new products from waste streams, regenerating and repurposing membranes to reduce water reuse costs, and producing activated carbon from sludge to minimize costs of micropollutant removal).

A recent study [123] concerned the categorization of the main water-consuming applications within industries, such as cooling water, boiler feed, the washing of vehicles, and water for recreational purposes. In addition, water reuse in agriculture and directly at the wastewater treatment plant were investigated, representing a topic with large interest within industries.

A recent industrial initiative was carried out in Kalundborg, including public and private companies [124], foreseeing the growing of algae on process water in an IS context. 
Based on the use of industrial process water as a resource, water remediation, production of microalgae biomass, and related technologies were tested.

\subsection{The Cement Sector}

Cement production begins with limestone, clay, and sand, and it represents one of the leading building materials. Its production is characterized by different steps, such as raw material preparation, clinker production, and cement preparation [125]. The most common form of cement is Portland cement, which is based on primary raw materials and generally is associated with large amounts of fossil fuels. Portland cement consists of 93-97\% clinker, which is formed when the raw limestone burns at a high temperature in a cement kiln [126]. Clinker production represents the most energy-intensive step in cement making, and it occurs in a kiln where raw materials, such as limestone, shale, or clay, plus others, are heated up to $1450{ }^{\circ} \mathrm{C}$. The kiln can be fired by fossil fuels (e.g., natural gas, coal), but these can be replaced with alternative fuels (e.g., waste-derived fuels, tyres, etc.) [127] Over the last few decades, the cement industry has been committed to using different byproducts originating from other industrial sectors (such as the previously mentioned reuse of slag from the steel production cycle) as fuels and raw materials [128], resulting in $\mathrm{CO}_{2}$ emissions reduction $[129,130]$. For this reason, in industrial ecology, the cement sector is defined as a "scavenger" [131].

Many scientific results on the cement sector were found in recent studies dealing with the most relevant achievements in industrial ecology and IS [132]. In particular, the relevance of the leading ideas for IS for the cement industry was studied [133]. The investigation was based on a quantitative comparison of the $\mathrm{CO}_{2}$ emissions from different cement production systems and products, both existing and hypothetical. In addition, thanks to the eco-town project Kawasaki Eco-town, which included more than 70 companies, a cement producer reduced $\mathrm{CO}_{2}$ emissions by 43,000 t per year by using recycled materials instead of virgin materials [134].

\subsection{The Ceramics Sector}

The European ceramic industry includes world-leading companies and SMEs that provide value-added solutions through mineral raw material transformation into sustainable and innovative products [135]. Due to its features, ceramic is a highly durable material with an estimated lifetime of more than 50 years. Furthermore, it is a material that is easily recyclable and recoverable in processes, reusing fired and unfired waste as well as demolition waste, according to the CE perspective [136].

The European ceramic industry includes nine sectors, ranging from construction products and consumer goods to industrial processes and cutting-edge technologies [135]. European data shows that its production is around 1304 million $\mathrm{m}^{2}$, consumption amounts to 964 million $\mathrm{m}^{2}$, and total sales were about EUR 9 billion in 2016 [137]. Within several subsectors, the ceramic industry includes floor and wall ceramic tiles, which is the most important ceramic subsector. In addition, the most common ones are earthenware tiles, glazed stoneware tiles, and porcelain stoneware tiles [138]. In Europe, the largest producers are Spain and Italy, which account for around $80-90 \%$ of the total European production [137].

The ceramic sector, due to its combustion processes, is considered as energy intensive and, accordingly, it is subject to European policies aiming at reducing GHG emissions. The production process consumes high amounts of energy; in addition, energy costs represent a significant part of the total production costs [139]. On this subject, according to "Roadmap for moving to a competitive low-carbon economy in 2050", the objective for the industrial sectors is $\mathrm{CO}_{2}$ emission reductions from $83 \%$ to $87 \%$ by 2050 [35]. Consequently, in "Paving the way to 2050-The Ceramic Industry Roadmap", alternative energy sources and current and future production of technologies were presented by considering the complete life cycle of ceramics [140]. The ceramic industry is consistently committed to developing innovative and high-value solutions [141] within several applications, from construction to consumer goods to industrial processes and cutting-edge technologies. Therefore, it is continuously 
committed to reducing costs, improving product reproducibility, and competing with other markets' products through development of new equipment and improving knowledge of ceramic properties and evolution [142].

Together with the reduction of $\mathrm{CO}_{2}$ emissions and wastewater, the ceramic sector is committed to recovering and recycling production residues whenever possible [140]. In particular, unfired waste tiles, fired waste tiles, washing line sludge, polishing and honing sludge, dried milling residues, and exhausted lime can be internally used by saving other raw materials, such as sands, feldspars, alumina, zirconium oxide, mullite, and clays. In particular, extraction, transport, and use of thousands of tonnes of natural materials can be avoided [136]. For instance, in Italy, $99.5 \%$ of the sector's production and purification waste is reused within the production route, recovering $8.5 \%$ of the minerals required in the manufacturing process. In addition, in $2015,70 \%$ of the required water in the Italian ceramic industry came from recycled wastewater [127]. In particular, in the Italian region of Emilia Romagna, the regional government indicated four byproducts from the ceramic sector that can be effectively used within the ceramic production process [143]:

- Unfired ceramic powders and bodies;

- Powders from fired ceramics;

- Unfired formed ceramic products (whole or fragments); and

- Fired formed ceramic products (whole or fragments).

On this subject, some companies of the "Zona Industriale Prataroni", a ceramic industrial district located in Civita Castellana in Emilia Romagna (Italy), joined the APEA ZICC (Zona Industriale Civita Castellana) to adopt a CE created by an IS approach, through both circular and green-economy-based applications. All the involved companies share their wastes, plants, and know-how to produce water for ceramics manufacturing and thermic and electric energy for self-consumption [144].

\subsection{Waste Treatment Sector}

The waste of electrical and electronic equipment (WEEE) sector includes a variety of end-of-life equipment from obsolete electrical appliances and electric goods [145], and metals represent $60 \%$ of equipment weight [146]. The major fraction of metals is concentrated in specific components, such as the printed circuit boards (PCBs), which contain copper, lead, tin solders, and precious metals [147]. Some products, comprising phosphors as fluorescent lamps, neodymium-iron-boron ( $\mathrm{NdFeB}$ ) magnets, and nickel-metal hydride (NiMH) batteries, contain REEs, which are lanthanides group elements plus scandium and yttrium. The European Commission classified REEs as the most critical raw materials, due their high economic value and intrinsic shortage $[148,149]$. A second source of valuable metals is represented by batteries, in particular lithium-ion batteries. Starting from their commercialisation in the early 1990s, lithium-ion batteries are a significant energy storage technology, due to their high energy density. This led to the quick development of portable electronics, such as mobile phones, laptops, and tablets. In addition, in the last 10-15 years, lithium-ion technology has strongly entered into the transport sector, due to its application in electric and hybrid cars, buses, trucks, and many energy storage systems. This has resulted in an increasing requirement to recycle lithium-ion batteries, although the levels are still insufficient. In 2019, the total weight of lithium batteries in the global market amounted to $1.25 \mathrm{Mt}$, while the recycled fraction was less than 10\% [150].

The lithium-ion battery value chain includes six steps: (1) mining and processing of raw materials; (2) cell component manufacturing; (3) cell manufacturing; (4) battery pack manufacturing; (5) installation in an electric vehicle; and (6) recycling [150]. Between steps 5 and 6, a lithium battery can be reused in a different application. Valuable metals contained in a lithium battery are critical raw materials and their recycling is important to reduce energy consumption, relieve the shortage of rare resources, and reduce the pollution of hazardous components.

WEEE is a growing waste stream in the EU and is hardly recycled. However, the EU aims at achieving CE, and WEEE should be seen as a source of valuable materials to 
be exploited. In 2019, only $17.4 \%$ of global e-waste was recycled, according to the WEEE Forum [151], corresponding to more than 40 million tonnes of e-waste generated globally in 2019 that were landfilled, burned, or illegally traded. This has led not only to the loss of valuable and critical raw materials, but also to environmental, health, and societal issues. While in the EU, e-waste recycling represents the highest level in the world thanks to appropriate legislation, only $17.4 \%$ of e-waste is collected and recycled [152].

Although WEEE is perfect for implementing an IS model, securing responsible sourcing of these materials and increasing their recycling rates represent a complex challenge. This can be due to different reasons, such as a lack of structured data on quantities, concentrations, trends, and final whereabouts in different waste flows in the urban mine in Europe, as well as efficient technological solutions for selecting and recovering materials [153]. Only policies and legislation that adopt sustainable strategies, including reuse and remanufacture, can lead to a favourable environment for developing IS models in this sector. However, the market shows some examples of practical implementation [154].

Some technological aspects are not advantageous. In particular, the applicable technologies are not efficient enough, implying relevant energy consumptions and high emissions in air and water. In particular, the existing technologies for WEEE recycling are mainly based on smelting processes and/or hydrometallurgical treatments, which significantly impact the environment by generating secondary pollutants. The development of environmentally friendly and cost-effective treatments is strongly required. In addition, the current recycling industry is not efficient enough for recovering metals from WEEE. Furthermore, while base metals (e.g., aluminium, copper, etc) and precious metals are extracted and recycled in significant amounts, REEs are seldom recycled. The WEEE recycling chain includes three main steps: (i) collection, (ii) pre-treatments, and (iii) end-refining processing [155]. Collection strongly depends on consumer awareness to provide electronic waste available for recycling, as well as on logistics and organization. Pretreatments should be improved to reduce the costs and increase the efficiency of valuable material yields. In addition, shredding, screening, magnetic separation, eddy current separation, corona electrostatic separation, and density-based separation are present in a conventional WEEE mechanical treatment line. Mechanical processes are applied in recovering mass relevant metals, such as iron and copper, reaching yields up to $80 \%$, while they fail in recovering precious metals [155]. End-refining processing requires special technologies. In particular, non-metallic fractions can be treated through gasification, pyrolysis, supercritical fluid depolymerization, and hydrogenolytic degradation, aiming at producing chemical substances and fuels. Metallic fractions are sent for further recovery via metallurgical techniques, such as pyrometallurgy and hydrometallurgy. Usually, electrometallurgical processes, such as electrowinning and electrorefining, are applied at the end of the recycling process. These are based on the electrodeposition of metal concentrates in aqueous electrolytes or molten salts. In addition, in the last few years, biometallurgy has become a promising technique for metal recovery from WEEE, as it is economically and environmentally viable compared to conventional procedures. Further emerging technologies such as electrochemistry, supercritical fluids, mechanochemistry, and ionic liquids are being explored [155]. On this subject, recent research activities have led towards process optimization to recover precious metals and REEs. Recycling of WEEE is well recognized; however the effective recovery of materials from electronic waste is still a challenge from the technical, environmental, economic, social and cultural points of view. In this regard, some lines of development have been identified [155]:

- Due to WEEE complexity, it is difficult to treat and recycle them. An improved eco-design approach can lead to easier recycling procedures.

- As a large amount of valuable materials is lost through the entire recycling chain, new advanced and efficient technologies for sorting, treating, and recovering metals are required to increase the yield and recycle more metals. 
- It is also important to improve the awareness of consumers, as well to develop infrastructures for collecting and treating WEEE in a more sustainable way, including other valuable metals that are still neglected, such as REEs.

- A virtuous cooperation and coordination among the stakeholders involved in the WEEE management system is crucial, while also taking into account regulations and policies.

\section{Energy Efficiency across Sectors}

In EIIs, energy can account for up to $25 \%$ of operating costs, representing a key factor for increasing its competitiveness [156]. This is one of the main reasons that for many years, EE has been a relevant objective for most EIIs in Europe and worldwide, and this concept was widely affirmed before IS. In the following, a review of the activities and trends of the research and development activities toward EE in the analyzed sectors of the European process industry is proposed.

\subsection{Iron and Steel Sector}

The steel industry is considered as one of the main resource consumers, and produces significant volumes of byproducts, wastes, and emissions. EE is a key driver for this sector [157]. Over the last 20 years, the steel industry made great efforts to reduce energy consumption in its production processes and improve efficiency in iron and steel manufacturing [158]. The improvement of socio-economic and environmental sustainability of its production processes is a key and crucial commitment of the European steel sector, to increase its resource efficiency and reduce its environmental footprint in steel production. Since 2013, "sustainable steel production" has been the highest priority within the strategic research agenda of the European Steel Technology Platform [159]. In addition, improving the product quality in needed in order to face increasing competition.

According to the "Best Available Techniques (BAT) Reference Document for Iron and Steel Production" [160], to achieve EE in the steel sector, the optimization of the off-gas management in an integrated steelwork represents a key factor. For instance, process off-gases produced in BF can replace natural gas, due to their significant energy content. Process gases can be considered as an intermediate byproduct to produce other valuable energy carriers or products, leading to a significant environmental benefit. Although off-gases are currently reused outside steel production, such as in power plants or heat and steam production, new developed approaches (e.g., decision support system) can be exploited to be applied in other sectors. Machine-learning-based approaches have been applied to estimate off-gas production (and the energy content) and demand from the different processes on a short-term horizon $(2 \mathrm{~h}$ with a sampling rate of $1 \mathrm{~min}$ or $5 \mathrm{~min}$ ), including energy transformation equipment [161,162]. In particular, echo-state neural networks (ESNs) and deep ESNs (i.e., specific recurrent neural networks) are very effective for modelling dynamic processes, with starting from process data also being computationally efficient [163]. In [164,165], deep echo-state neural networks (ESNs) also were applied to modelling nonlinear dynamics of complex industrial processes (e.g., forecasting energetic content in BF gases during the hot metal production, and developing the application of its consumption in hot blast stoves) [162]. These machine-learningbased models were used to optimize the gas distribution inside the network, taking into account possible interactions [166]. Moreover, a series of key performance indicators were elaborated to monitor the gas management efficiency, and the overall economic and environmental objectives of the optimization were defined [167]. An offline tool for overall structural optimization of the network was developed (see Figure 6). 


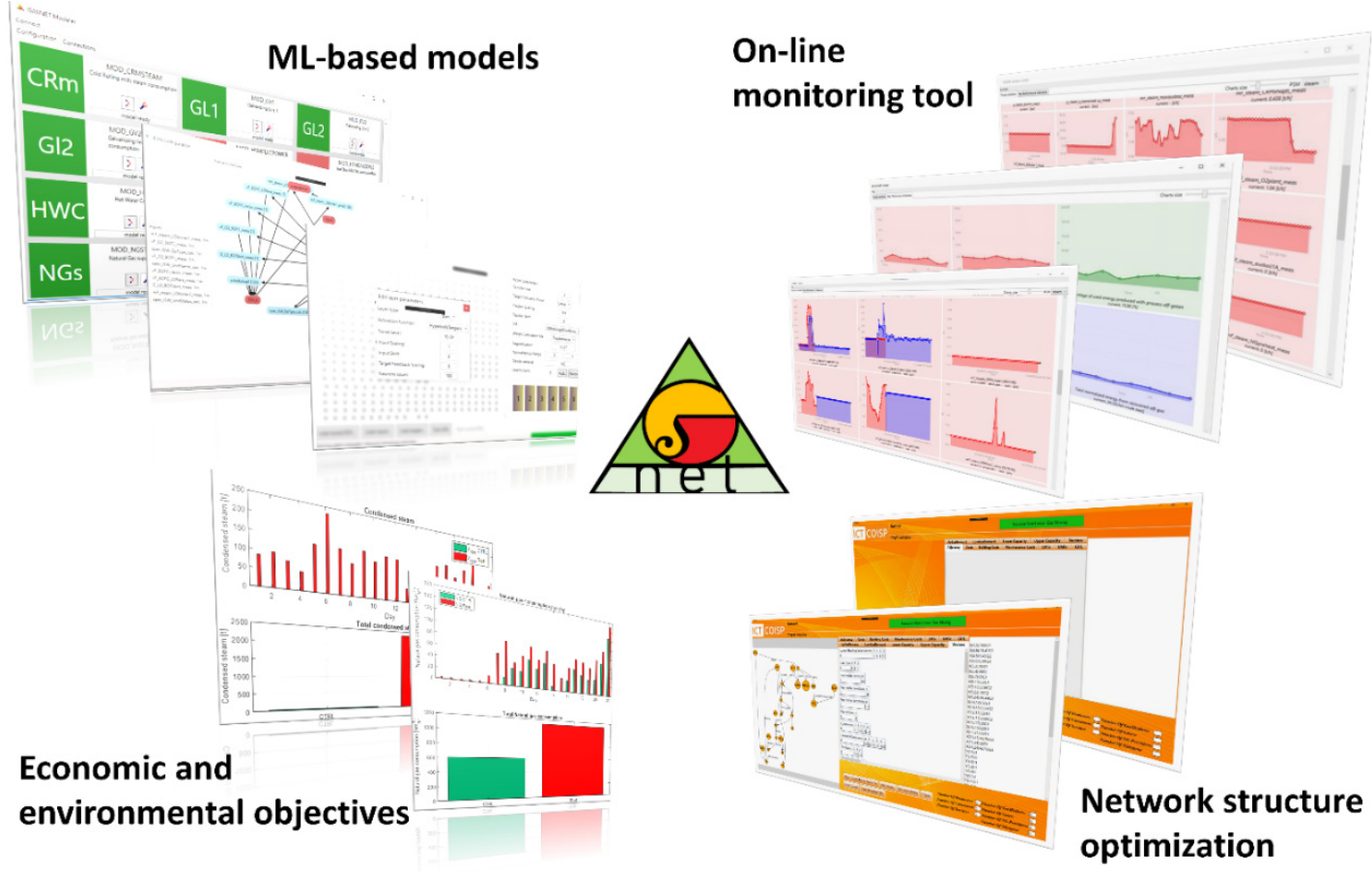

Figure 6. Conceptual scheme of the decision-support tool for optimal management of the gas and steam network in integrated steelworks.

As far as the electric steelmaking route is concerned, scenario analyses were carried out to find process modifications, and improve the sustainability of a production cycle including EE by exploiting an assessment and simulation tool based on the definition of key performance indicators, and on the Aspen Plus ${ }^{\circledR}$ modelling [168-170].

Process integration models aim at improving material and energy efficiency, as well as environmental and economic sustainability of both the scrap-based [82] and the integrated route [171,172]. Process integration solutions targeting wastewater management and reuse also were investigated $[173,174]$; these allow savings of both freshwater and energy costs related to freshwater extraction.

Improving EE by investigating strategies for hot blast stoves was studied [175]. The development of a mathematical model was carried out to assess hot blast stoves' performance, using a finite differential approximation to represent the heat transfer inside the furnace during operation. The temperature distribution and the state of charge of the hot stoves were estimated and predicted online through a control model, supporting decisions of the plant operator.

In the steel industry, the traditional approach is still production-driven. By combining scheduling and optimization of energy procurement as an integrated monolithic optimization model, this results in intractable problems requiring excessive computational time to be solved [176]. A mean value cross decomposition was used to solve the combined problem by iterating between energy-aware production scheduling and energy-cost optimization, and adopting mixed-integer linear programming (MILP)-based models for the formulation of the scheduling problems, while for the energy cost, optimization with a minimum-cost flow network was used [177]. Moreover, advanced modelling and optimization approaches were applied to intelligent planning of energy-intensive operations to meet the constraints of the external energy grid, avoid over-consumption, and take maximum advantage of the country-specific energy market possibilities [178,179] (see Figure 7 for an example of the developed interface). 


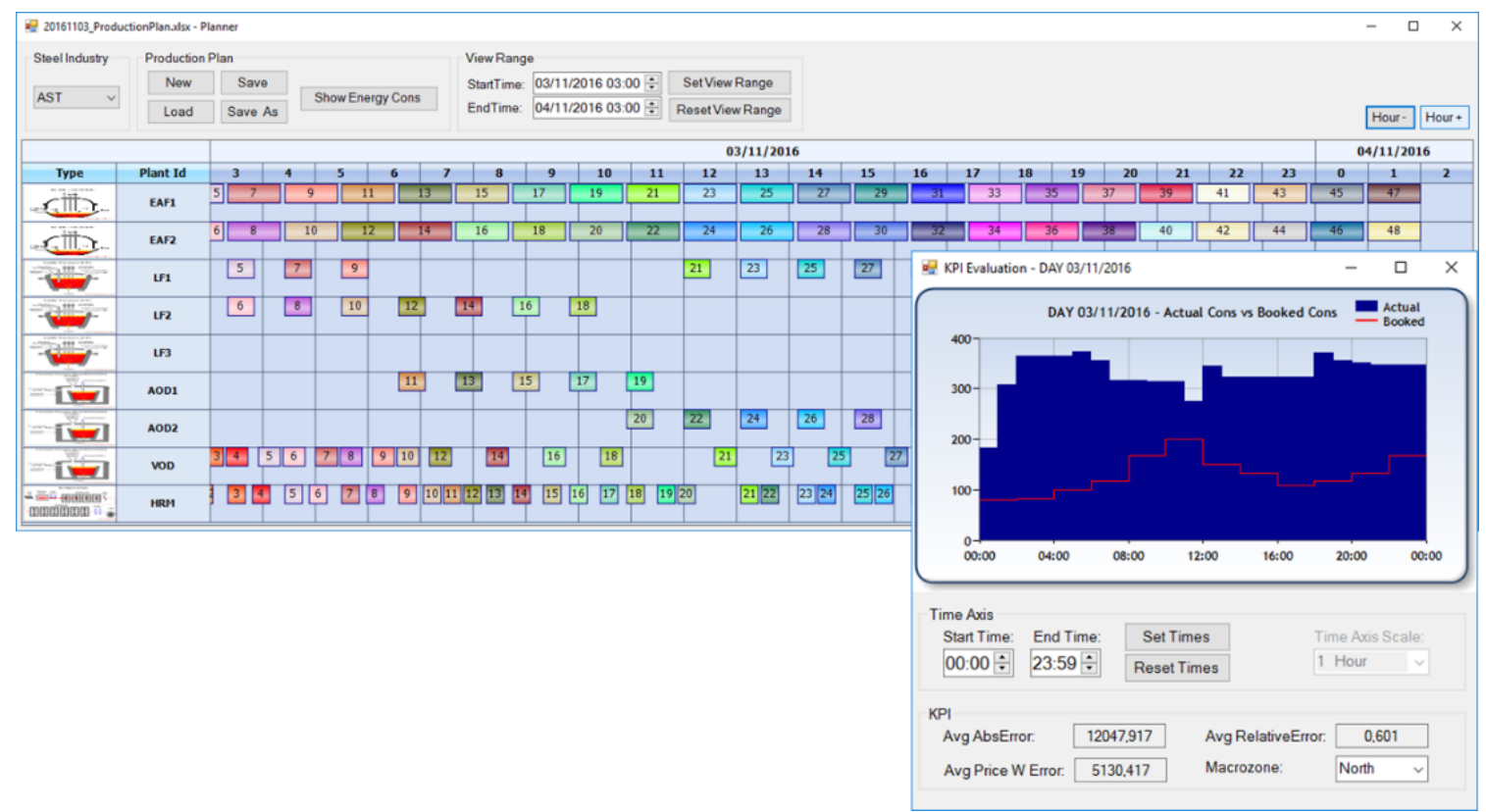

Figure 7. Exemplar interface for scheduling management targeting power-consumption optimization in electric steelworks.

In a recent analysis concerning the Swedish steel industry [180], some relevant barriers for implementing EE measures were identified: lack of time, lack of personnel, unclear information from the technology supplier, risk of production disruption, other priorities for capital investments, lack of people with a higher education in the energy field, and lack of awareness of the potential of engaging employees. Energy use and EE measures/technologies in the steel sector were reviewed in [158], resulting in large number of energy-efficient, cost-effective, and available technologies that can help energy managers select areas for energy-efficiency improvements. The implementation of more efficient technologies, energy recovery in the manufacturing processes, increased energy conversion efficiency, and optimisation of operational practices can lead to relevant EE improvement.

\subsection{Chemical Sector}

\subsubsection{The Refinery Industry}

Complex refineries, as EIIs, are committed to limiting energy consumption. In particular, there are several actions focused on improving EE, such as: increasing heat interchange between process streams; thermal exchange within and between process units and hotter charge feed between units; use of more efficient heaters or furnace processes; gas turbines with pre-heated air; and waste heat steam generation (when feasible).

In the last few years, the current specific consumptions (the ratio between the energy consumed by the refinery and the tonnes of feedstock processed) of a sample of European refineries ranged from $1.5 \mathrm{GJ} / \mathrm{t}$ to $4.0 \mathrm{GJ} / \mathrm{t}$ of crude, with an average of $2.75 \mathrm{GJ} / \mathrm{t}$. Around $3-9 \%$ of the crude feedstock is burnt in the refinery [181].

The energy losses from petroleum-refining operations are primarily the result of the following:

1. Heat rejected by (lost to) air- and water-cooled heat exchangers, used to cool recycled and product streams. It represents $55 \%$ of the total losses.

2. Unrecovered heat in flue gases from furnace and steam boiler losses are $19 \%$ of the total losses.

3. Convection and radiation losses from hot equipment, transitional tanks, and piping are $18 \%$ of the total losses.

4. Steam system losses are $3 \%$ of the total losses.

5. Organic landfilled wastes are $5 \%$ of the total losses. 
Table 1 reports the potential recoverable energy.

Table 1. Potential energy recoverable in refineries.

\begin{tabular}{ccc}
\hline Refinery Sections & $\begin{array}{c}\text { Energy Losses } \\
\left(\mathbf{M J} / \mathbf{t}_{\text {crude }}\right)\end{array}$ & $\begin{array}{c}\text { Potential } \\
\text { Recoverable Energy } \\
\left(\mathbf{M J} / \mathbf{t}_{\text {crude }}\right)\end{array}$ \\
\hline $\begin{array}{c}\text { Cutting oil at high temperature } \\
\begin{array}{c}\text { Heat rejected by (lost to) air- and water-cooled } \\
\text { heat exchangers used to cool recycled and } \\
\text { product streams }\end{array}\end{array}$ & $550-2200$ & $150-600$ \\
\hline $\begin{array}{c}\text { Waste heat between production units } \\
\text { Unrecovered heat in flue gases from furnaces } \\
\text { and steam boilers }\end{array}$ & $200-1000$ & $70-350$ \\
\hline $\begin{array}{c}\text { Heat losses from processes } \\
\text { Convection and radiation losses from hot } \\
\text { equipment, transitional tanks, and piping }\end{array}$ & $100-400$ & $30-120$ \\
\hline Heat from tapping streams & $30-120$ & $10-36$ \\
\hline Wastes & $50-120$ & $15-40$
\end{tabular}

Data estimates at present (see Figure 1) show that the potential recoverable energy is about $30 \%$ (from $0.24 \div 1.2 \mathrm{GJ} / \mathrm{t}$ of crude) of the actual specific losses.

Over the last few years, EE in refineries has increased, due to some economic issues, such the increased cost of fuel consumption. However, the corresponding efficiency has increased with the fuel price. According to the research activities performed by the American Petroleum Institute (API), significant reductions in energy consumption can be achieved through investments in new plants, operational improvements, and modernization of old equipment.

\subsubsection{Consumer Goods Companies}

Since 1970s, European goods industries were committed to a more efficient energy use. Globally, $37 \%$ of primary energy of this sector is converted to useful energy, resulting in about two-thirds of losses [182]. In the next 20 years, energy efficiency will achieve 25-35\% in industrialised countries and more than $40 \%$ in transition economies. In addition, dematerialisation and recycling will further contribute to energy-intensity reduction. Although benefits from consumer goods' energy efficiency have been traditionally underestimated by energy policies, achievable EE levels depend on countries industrialisation, motorisation, electrification, human capital, and policies. However, the implementation of EE actions can be affected by specific barriers, such as lack of knowledge, or legal and administrative obstacles. On this subject, governments and companies can lower these barriers, but international harmonisation of regulations also can play a crucial role in efficiency of traded products. Thanks to new technologies and cost reductions, the economic potentials deriving from more efficient energy use in this sector will continue to grow.

Several European programs are focused on EE, and most of them are centred on the consumer goods industries. In particular, the Intelligent Energy Europe Program (IEE) [183], established with Decision No. 1639/2006/EC [184], aims at promoting EE, renewable energy sources, and energy diversification. It contributed to ensuring safe and sustainable energy for Europe through the support of European countries committed to achieving the objectives of the European 2020 strategy ( $-20 \%$ greenhouse gas emissions; $+20 \%$ energy efficiency; $+20 \%$ renewable energy) [24], as well as to strengthening competitiveness with measures encouraging EE and rational use of energy resources [185], with particular focus on consumer goods companies. 


\subsection{Non-Ferrous Metals Sector}

The non-ferrous metals industry is the sector with the highest share of electrical energy use. In particular, in 2017, the total energy use in the European non-ferrous metals industry was 432 petajoules (PJs), corresponding to $120 \mathrm{TWh}$. Electricity is the most important energy carrier, with a share of 58\% of final energy use (69 TWh) [186].

In aluminium production, the primary aluminium requires $14-16 \mathrm{MWh} / \mathrm{t}$ of electrical energy, accounting for about $85 \%$ of total energy consumption, while secondary aluminium requires $0.12-0.34 \mathrm{MWh} / \mathrm{t}$ of electrical energy. Concerning copper (total energy $3.3 \mathrm{MWh} / \mathrm{t}$, electrical energy 1.5 MWh/t), zinc (total energy $14 \mathrm{MWh} / \mathrm{t}, 1 \mathrm{MWh} / \mathrm{t}$ electrical energy), and other metals, less specific energy is required. However, for producing these metals, more fossil fuels are consumed, and more specific $\mathrm{CO}_{2}$ emissions are produced [186].

Over the last few decades, significant reductions in $\mathrm{CO}_{2}$ emissions have been achieved. In particular, between 1990 and 2015, the non-ferrous metals industry reduced $\mathrm{CO}_{2}$ equivalent emissions (direct and indirect) by about $61 \%$ [186]. This was mainly due to significant reductions of perfluorocarbon (PFC) emissions (mainly produced in the primary aluminium production process), which have a significant greenhouse effect. On this subject, the aluminium sector was committed to reducing emissions through process improvement, and implementation of monitoring and control systems. On the other hand, reducing energy consumption contributed to reducing $\mathrm{CO}_{2}$ emissions. In addition, technological evolution has led to significant reductions in energy consumptions of around $15 \%$. Significant improvements were achieved by introducing new plants, new operating activities, larger number of sensors, control systems, and higher automation. Furthermore, the use solid fuels and oil decreased from $11 \%$ and $12 \%$, respectively, in 1990, and was down to $3 \%$ in 2017. Their replacement by natural gas and electrical energy contributed to increasing EE and reducing $\mathrm{CO}_{2}$ emissions.

The EU non-ferrous metals sector represents the most efficient producer worldwide, with a strong secondary production due to improved recycling and recovering of metals from scrap and byproducts. Further reductions of total energy consumption $(20 \%)$ will be achieved by 2050 [42]. A set of energy-saving opportunities in this sector were assessed. They came from ongoing technological developments, including:

- New technological solutions for plant and process optimization;

- Integrated control system of the process steps, supported by AI;

- Flue gas monitoring system to maintain proper air-to-fuel ratio;

- Measurement of the energy consumption of single units and equipment for optimization;

- Preventive furnace maintenance;

- Inert anodes;

- High-efficiency burners;

- Systems for energy recovery from exhaust gas;

- Low-temperature waste heat recovery for power generation (e.g., using the organic Rankine cycle); and

- Digitalisation and introduction of measures to favor EE.

\subsection{The Mineral Sector}

The mineral industry consumes a significant amount of energy in many economies. In particular, its electricity consumption represents a significant portion of the energy use in developing countries. As energy is consumed in all the processes of the mineral cycle, the mineral industry is deeply committed to reducing its energy consumption and promoting EE initiatives, not only due to energy costs [187], but also to climate-change impacts and the carbon footprints of products. In addition, the growing energy demand has been the driver for increasing use of renewable energy sources [188]. For instance, the integration of solar energy in mines' energy supply can help address EE and sustainability [189]. Recently, the technical and economic viability of installing an energy recovery system on diesel electric drive mine hauling trucks was investigated using simulations [190]. Furthermore, in order 
to assess the EE increase, it is important to study how energy is consumed in different mining processes. For instance, the electrical energy consumption in mining operations treating sulphide ores was recently described [191]. Sulphide ores represent $80 \%$ of the worldwide primary copper production. The energy demand and the characterization of electrical energy consumption of the different processes to mine and process sulphides ores were described. These aspects are fundamental in designing strategies for EE and smart energy management. Another significant example is represented by a framework to assess dragline EE by using equipment monitoring data [192]. A three-step approach was presented, involving: (1) assessment of EE using data from dragline monitoring systems to estimate an overall performance indicator; (2) quantification of the relationships between different operating parameters and the EE indicator; and (3) improvement of EE performance of operators, using results to optimize operator training. In addition, plant process control and real-time optimisation approaches were described [193]. They were used to reach lower specific energy requirements by lowering variability in key process variables and by determining more appropriate operating points.

Future studies should consider holistic, systems-based approaches to optimizing EE and aim at facilitating optimal integration of renewable energy sources into mines.

\subsection{The Water Sector}

In Europe, manufacturing industries use about 37,000 million $\mathrm{m}^{3} / \mathrm{y}$ of freshwater, by recycling it up to 10 times with the specific electric energy consumption more than $0.2 \mathrm{kWh} / \mathrm{m}^{3}$. Nowadays, in industrial water circuits, a benchmark for energy consumption, tools focused on its systematic reduction, as well as awareness of the saving potentials, do not exist. However, European EIIs are committed to achieving sustainable uses of water, as it is generally used for process and heat-transfer purposes. Industries aim at directly and indirectly contributing to water scarcity and pollution. For this reason, a growing number of companies have begun to investigate their water footprint (WF) and ways to improve it [194]. In addition, comparison between new perspectives of water use and traditional ways was performed. In several industries, different quantities of water are consumed, depending on industry features, technologies used in production processes, etc. Cleaner production processes, and reducing water consumption and wastewater discharged from production processes, represent actions to be developed by EIIs [195]. Over the last few decades, new strategies for wastewater treatment, such as converting wastewater into energy or other resources, have been developed. On this subject, great efforts have made in developing and applying new processes and technologies for wastewater reuse, in order to achieve a sustainable management of water resources.

Over the last few years, energy consumption has significantly increased, due to new technology implementations to meet new quality standards. High energy consumption will affect the water industry worldwide, and it is also linked to the issue of climate change [196]. Consequently, for water and wastewater companies, energy represents the highest operating cost after manpower. The price of energy has also increased due to the need to meet future changes to regulations and standards.

In order to achieve energy cost savings in the water and wastewater sector, electricity efficiency improvements are crucial. In particular, progress in the large energy end-uses of pumping, aeration, and sludge treatment represent the best potential savings. In particular, as pumping accounts for over $80 \%$ of total electricity use in public water supply systems and for over $50 \%$ in wastewater treatment facilities, efficiency improvements can lead to significant energy savings for the water and wastewater industry. Electric efficiency measures, resulting in energy cost savings potential, include: regular infield pump testing to determine actual pump performance and the need for repair and replacement; use of variable frequency drives to control pump speed and flow rather than throttling valves for fixed-speed drives; use of supervisory control and data acquisition (SCADA) systems to continually optimize pumping performance; and replacing older, inefficient engines with high-efficiency or premium-efficiency engines [197]. In general, water circuit simulations 
involve fluid-dynamic parameters; part of them are measurable, but other effects are not directly measurable. As these effects have a strong influence on the water circuit behaviour, but they cannot be directly introduced in a fluid-dynamics tool, the use of techniques, starting from historic and measured data, can provide information to efficiently tune the global approach. Finally, combined cooling, heating, and power systems present energy-saving, environmentally friendly and cost-saving characteristics. Conventionally, combined cooling, heating, and power systems use the water- $\mathrm{LiBr}$ absorption chiller to meet the cooling demand [198].

\subsection{The Cement Sector}

The cement industry is an EII, and it is one of the most energy-intensive industrial sectors. It accounts for almost $15 \%$ of the total energy consumed in the manufacturing process. On average, for one tonne of cement produced, $3.4 \mathrm{GJ}$ of thermal energy (in the dry process) and $110 \mathrm{kWh}$ of electrical energy are required [199]. The cement industry is highly energy- and material-intensive, and is responsible for more than $5 \%$ of global $\mathrm{CO}_{2}$ emissions. In addition, it releases significant $\mathrm{SO}_{2}$ emissions, $\mathrm{NOx}$, and other pollutants [200]. However, over the last few years, remarkable initiatives and studies in this sector have been focused on EE improvement. They aim at both decreasing energy consumption and $\mathrm{CO}_{2}$ emissions, and maintaining the high quality and capacity of production processes [201]. On this subject, several technologies have been implemented. In particular, it is important to highlight energy-efficient technologies, such as product and feedstock modification. In particular, manufacturing low alkali and limestone cements are alternatives that can reduce the consumption of thermal energy [202] as well as alternative fuels and recovering energy actions and systems that reduce $\mathrm{CO}_{2}$ emissions [203]. In order to improve $\mathrm{EE}$ in the cement sector, recently, a decision-making model has been developed [201] that supports the selection of EE measures.

\subsection{The Ceramics Sector}

Within EIIs, the ceramic industry is one of the industrial sectors with the highest energy consumptions, as large amounts of energy during the ceramic manufacturing processes are consumed. In ceramic manufacturing, the processes in which thermal energy is mainly consumed are spray drying of ceramic slurries (36\%), drying of the formed ceramic tile bodies (9\%), and ceramic tile firing (55\%) [204]. However, firing is the main factor responsible for energy consumption in the production process, accounting for 50 $60 \%$ of the total energy consumed. During firing, in furnaces very high temperatures can be reached, ranging between $800{ }^{\circ} \mathrm{C}$ and $1200{ }^{\circ} \mathrm{C}$. This process requires high amounts of fossil-fuel consumption, especially natural gas [204]. However, there is significant room for improving EE. Concerning electric energy, its consumption represents up to $30 \%$ of the production cost in ceramics manufacturing, but variations are possible, due to the product type and the cost of fuel [205]. Consequently, reducing energy use and cost can lower production costs, leading to an immediate impact on profit [206].

Radical or incremental innovations related to process (e.g., electric-field-assisted sintering techniques or vacuum drying) and product innovations (e.g., zero-energy coatings) could be used to further reduce the energy demands of the processes [207].

\section{Conclusions}

This study described current and future challenges faced by different industrial sectors in adopting developments of IS and EE, to propose future suitable enhancements and new research directions. The literature review was not intended to be exhaustive, but it provides an overview of the currently available practices. The assessment of local realities in terms of existing industries, legislation, and other constraints can be the best method for further dissemination practices.

The pursued analysis of the state of the art in IS in different EIIs provided significant examples focused on optimisation of resource use and on reduction of the amount of 
byproducts/waste generated to improve their environmental, economic and social performances. According to the IS concept, results include the use of byproducts/waste from a sector as inputs to other sectors, transactions of utilities or access to services, and cooperation on issues of common interest.

Synergies within companies, according to the IS concept, can provide benefits to all involved actors. In particular, developing symbiotic networks can facilitate resources supply and can reduce the vulnerability of the network, resulting in higher energy efficiency and higher results in the $4 \mathrm{R}$ (reduce, reuse, recycle, and restore) approach for the byproducts/waste management. In particular, transaction services between industries provide new and common market solutions, and business and cooperation models. In addition, data management opportunities can allow product customization and new decision and management tools to improve IS activities. IS measure implementation can make EIIs more efficient and can reduce negative impacts of their process, in terms of EE and environmental impacts. In addition, the performed analysis on IS highlighted existing synergies and the creation of new symbiosis networks. Finally, specific barriers have been identified, and impacts on companies, the environment, and society, by considering different aspects of the network and features of the involved region. This will result in novel decision-making approaches supporting final strategic decisions.

The analysis of the state of the art of EE in EIIs underlines the efforts towards crosssectorial novel solutions and strategies for reducing energy use and related environmental impacts and costs. Advanced technologies for producing, using, and recovering energy have been identified, to reduce companies' energy losses and valorise energy waste streams that could be a valuable resource for another company. For instance, in the steel sector, the reduction of product life cycle energy use and emissions can be achieved by improving product design, recovery and reuse, remanufacturing, and recycling. In addition, synergies among companies aim at optimizing energy consumption and common productions to reduce the use of fossil fuels and, consequently, the carbon footprint, as well as the investment, maintenance, and management costs of the energy infrastructure. Furthermore, cooperation within different industrial sectors can allow overcoming the lack of technical knowledge on low carbon and renewable technologies and on cost savings.

Further EE improvements are expected in EIIs through technology transfer and by applying best-available technologies. On this subject, suitable energy system models should include some significant features, as follows: multiobjective optimization, facilitating minimisation of costs and carbon emissions; technological descriptions at the unit level; sufficient temporal detail, showing energy demand; energy storage technologies and flexible energy demands; and system superstructures, enabling the introduction of energy service demand or energy production technology. Beside new and improved technologies, new sector overarching skills are also needed to improve the cross-fertilisation of technological development and implementation, as well as the cooperation across sectors in the sense of IS. Finally, amendments to existing regional/national/EU policies and legal frameworks to simplify energy cooperation/services at all governance levels can help improving EE in EIIs.

The analysis of the development and implementation of technical solutions and operating practices related to IS and EE in different European industrial sectors shows that this is an ongoing process involving production processes and services. This review work provides further information on how transactions of energy and material flows can enhance the companies' competitiveness by exploiting a cross-sectorial cooperative approach. Furthermore, being focused on the current state, upcoming techniques, and developments (based on the main CE transformation levers and technological market trends), this review paper aims at providing a complete picture of the sectors involved in their efforts in achieving more proactive cross-sectorial cooperation and integration. On the other hand, the analysis of the main drivers and barriers for IS and EE implementation can pave the way for further developments of EIIs that will aim at defining future scenarios for the European process industry in a context including material scarcity, decarbonisation of industrial processes, and stricter environmental policies. 
The conducted review work, by providing a comprehensive picture, can be a further driver to industries for closing more loops in the future for a sustainable future. In particular, to increase their competitiveness European EIIs should invest in new technologies for IS and EE activities, as well as in measures for adjusting the related skills, competences and experiences of the workforce. In addition, further knowledge on the broader systemic perspective and social dimensions of collaborative approaches is required in order to achieve more resource efficiency and, on the other hand, increased institutional capacity is necessary to facilitate and support these goals.

The performed analysis also allows identifying future research directions. Future activities can be focused on the quantification of the impacts of the three dimensions of sustainability, namely environment, economy, and society. In particular, the adequacy of the current skills and gaps to be filled should be assessed, to promote reskilling and upskilling processes and to search and form eventual new professional profiles. In this respect, new methods and specific indicators can be defined to quantify the total impact of IS and EE practices on companies and to help the decision-making process. This is fundamental to motivate companies to adopt these practices and can help to improve planning or designing future practices.

Author Contributions: Conceptualization, V.C., T.A.B. and B.F.; methodology, V.C. and T.A.B.; validation, V.C., A.J.S. and T.A.B.; formal analysis, V.C., T.A.B., F.C. and M.I.P.; investigation, T.A.B., B.F., M.I.P. and E.L.F.; resources, V.C. and A.J.S.; writing—original draft preparation, T.A.B. and V.C.; writing-review and editing, F.C., M.I.P. and A.J.S.; visualization, V.C. and T.A.B.; supervision, V.C.; project administration, A.J.S. and V.C.; funding acquisition, A.J.S. and V.C. All authors have read and agreed to the published version of the manuscript.

Funding: This research was funded by the European Union through the Erasmus Plus Programme (Grant Agreement No. 612429-EPP-1-2019-1-DE-EPPKA2-SSA-B).

Institutional Review Board Statement: Not applicable.

Informed Consent Statement: Not applicable.

Data Availability Statement: Not applicable.

Acknowledgments: The research described in the present paper was developed within the project entitled "Skills Alliance for Industrial Symbiosis: A Cross-Sectoral Blueprint for a Sustainable Process Industry (SPIRE-SAIS)", and was based on a preliminary deliverable of this project. The SPIRE-SAIS project was funded by Erasmus Plus Programme of the European Union (Grant Agreement No. 612429-EPP-1-2019-1-DE-EPPKA2-SSA-B). The sole responsibility of the issues treated in the present paper lies with the authors; the Commission is not responsible for any use that may be made of the information contained therein. The authors wish to acknowledge with thanks the European Union for the opportunity granted that made possible the development of the present work. The authors also wish to thank all partners of the project for their support and the fruitful discussion that led to successful completion of the present work.

Conflicts of Interest: The authors declare no conflict of interest.

\section{References}

1. Mallawaarachchi, H.; Sandanayake, Y.; Karunasena, G.; Liu, C. Unveiling the conceptual development of industrial symbiosis: Bibliometric analysis. J. Clean. Prod. 2020, 258, 120618. [CrossRef]

2. Fraccascia, L.; Yazdanpanah, V.; van Capelleveen, G.; Yazan, D.M. Energy-based industrial symbiosis: A literature review for circular energy transition. Environ. Dev. Sustain. 2021, 23, 4791-4825. [CrossRef]

3. Martin, M. Industrial Symbiosis Networks: Application of the Circular Economy for Resource Efficiency. In Handbook of the Circular Economy; Edward Elgar Publishing: Cheltenham, UK, 2020.

4. Neves, A.; Godina, R.; Azevedo, S.G.; Matias, J.C. A comprehensive review of industrial symbiosis. J. Clean. Prod. 2020, 247, 119113. [CrossRef]

5. Debnath, B. Towards Sustainable E-Waste Management Through Industrial Symbiosis: A Supply Chain Perspective. In Industrial Symbiosis for the Circular Economy; Springer: Berlin/Heidelberg, Germany, 2020; pp. 87-102.

6. Tanaka, K.; Managi, S. Industrial agglomeration effect for energy efficiency in Japanese production plants. Energy Policy 2021, 156, 112442. [CrossRef] 
7. Castro Oliveira, M.; Iten, M.; Cruz, P.L.; Monteiro, H. Review on Energy Efficiency Progresses, Technologies and Strategies in the Ceramic Sector Focusing on Waste Heat Recovery. Energies 2020, 13, 6096. [CrossRef]

8. Schwarz, E.J.; Steininger, K.W. Implementing nature's lesson: The industrial recycling network enhancing regional development. J. Clean. Prod. 1997, 5, 47-56. [CrossRef]

9. Chertow, M. Industrial symbiosis: Literature and taxonomy. Annu. Rev. Energy Environ. 2000, 25, 313-337. [CrossRef]

10. Lombardi, D.; Laybourn, P. Redefining industrial symbiosis: Crossing academic-practitioner boundaries. J. Ind. Ecol. 2012, 16, 28-37. [CrossRef]

11. European Committee for Standardization. Industrial Symbiosis: Core Elements and Implementation Approaches. Available online: https://www.cencenelec.eu/research/CWA/Pages/default.aspx (accessed on 22 March 2021).

12. Neves, A.; Godina, R.; Azevedo, S.G.; Pimentel, C.; CO Matias, J. The Potential of Industrial Symbiosis: Case Analysis and Main Drivers and Barriers to Its Implementation. Sustainability 2019, 11, 7095. [CrossRef]

13. Wolf, A.; Karlsson, M. Evaluating the environmental benefits of industrial symbiosis: Discussion and demonstration of a new approach. Prog. Ind. Ecol. Int. J. 2008, 5, 502-517. [CrossRef]

14. Karlsson, M.; Wolf, A. Using an optimization model to evaluate the economic benefits of industrial symbiosis in the forest industry. J. Clean. Prod. 2008, 16, 1536-1544. [CrossRef]

15. Jiao, W.; Boons, F. Toward a research agenda for policy intervention and facilitation to enhance industrial symbiosis based on a comprehensive literature review. J. Clean. Prod. 2014, 67, 14-25. [CrossRef]

16. Cervo, H.; Ferrasse, J.-H.; Descales, B.; Van Eetvelde, G. Blueprint: A methodology facilitating data exchanges to enhance the detection of industrial symbiosis opportunities-Application to a refinery. Chem. Eng. Sci. 2020, 211, 115254. [CrossRef]

17. European Commission. Roadmap to a Resource Efficient Europe COM (2011) 571 Final; European Commission: Brussels, Belgium, 2011.

18. European Commission. Closing the Loop-An EU Action Plan for the Circular Economy-COM(2015) 614 Final; European Commission: Brussels, Belgium, 2015.

19. European Commission. Directive (EU) 2018/851 of the European Parliament and of the Council of 30 May 2018 Amending Directive 2008/98/EC on Waste. 2018. Available online: http:/ / data.europa.eu/eli/dir/2018/851/oj (accessed on 1 July 2021).

20. European Commission. Measuring Progress towards Circular Economy in the European Union e Key Indicators for a Monitoring FrameWork 16.1.2018. SWD(2018) 17 Final; European Commission: Brussels, Belgium, 2018.

21. European Commission. Proposal for a Decision of the European Parliament and of the Council on Establishing the Specific Programme Implementing Horizon Europe e the Framework Programme for Research and Innovation; European Commission: Brussels, Belgium, 2018.

22. European Commission. Circular Economy Action Plan. For a Cleaner and More Competitive Europe; European Commission: Brussels, Belgium, 2020. Available online: https:/ / ec.europa.eu/environment/circular-economy/pdf/new_circular_economy_action_ plan.pdf (accessed on 1 July 2021).

23. European Commission. Communication No. 640, 2019. The European Green Deal; (COM no. 640, 2019); Commission of European Communities: Brussels, Belgium, 2019.

24. European Commission. Communication No. 2020, 2010. Europe 2020-A Strategy for Smart, Sustainable and Inclusive Growth; (COM No. 2020, 2010); Commission of European Communities: Brussels, Belgium, 2010.

25. European Commission. A Framework Strategy for a Resilient Energy Union with a Forward-Looking Climate Change Policy; COM/2015/080 Final, February 25; European Commission: Brussels, Belgium, 2015.

26. United Nations. Transforming Our World: The 2030 Agenda for Sustainable Development; A/RES/70/1; United Nations: New York, NY, USA, 2015.

27. Yang, G.C.; Chuang, T.-N.; Huang, C.-W. Achieving zero waste of municipal incinerator fly ash by melting in electric arc furnaces while steelmaking. Waste Manag. 2017, 62, 160-168. [CrossRef]

28. Ansari, N.A. Innovation through Recycling/Minimizing Waste. In Proceedings of the Innovation Forum, Oxford, UK, 7 February 2017.

29. Kiss, K.; Ruszkai, C.; Takács-György, K. Examination of Short Supply Chains Based on Circular Economy and Sustainability Aspects. Resources 2019, 8, 161. [CrossRef]

30. Branca, T.A.; Vannucci, M.; Colla, V. A KPI for Local Community Impact of the ULCOS technologies. Revue de Métallurgie 2009, 106, 373-381. [CrossRef]

31. Fossil Fuels Still Supply 84 Percent of World Energy-And Other Eye Openers from BP's Annual Review. Available online: https: / / www.forbes.com/sites/rrapier/2020/06/20/bp-review-new-highs-in-global-energy-consumption-and-carbonemissions-in-2019/?sh=204c2aa166a1 (accessed on 13 April 2021).

32. International Energy Agency Energy Technology Perspectives. Scenarios E Strategies to 2050; OECD Publishing: Paris, France, 2009; ISBN 978-926-408-598-5. 
33. European Parliament and Council. Directive 2012/27/EU of the European Parliament and of the Council of 25 October 2012 on Energy Efficiency, Amending Directives 2009/125/EC and 2010/30/EU and Repealing Directives 2004/8/EC and 2006/32/EC Text with EEA Relevance. Available online: https://eur-lex.europa.eu/legal-content/EN/TXT/?uri=CELEX: 32012L0027 (accessed on 1 July 2021).

34. The Macroeconomic and Other Benefits of Energy Efficiency. European Union, August 2016. Available online: https://ec.europa. eu/energy/sites/ener/files/documents/final_report_v4_final.pdf (accessed on 22 February 2021).

35. European Commission. Roadmap for Moving to a Low-Carbon Economy in 2050. Available online: https:/ / eur-lex.europa.eu/ LexUriServ / LexUriServ.do?uri=COM:2011:0112:FIN:EN:PDF (accessed on 22 February 2021).

36. European Commission. Energy roadmap 2050. Available online: https:/ / ec.europa.eu/energy/sites/ener/files/documents/20 12_energy_roadmap_2050_en_0.pdf (accessed on 22 February 2021).

37. Council of the European Union. Brussels European Council 8/9 March 2007; Council of the European Union: Brussels, Belgium, 2007.

38. European Environment Agency. COM(2005) 265 Final. Green Paper on Energy Efficiency or Doing More with Less; European Environment Agency: Copenhagen, Denmark, 2005.

39. European Environment Agency. COM(2006) 545-Action Plan for Energy Efficiency: Realising the Potential; European Environment Agency: Copenhagen, Denmark, 2006.

40. European Union. Directive 2006/32/EC of the European Parliament and of the Council of 5 April 2006 on Energy End-Use Efficiency and Energy Services and Repealing Council Directive 93/76/EEC. Available online: https://eur-lex.europa.eu/ LexUriServ /LexUriServ.do?uri=OJ:L:2006:114:0064:0085:EN:PDF (accessed on 1 July 2021).

41. Finnerty, N.; Sterling, R.; Coakley, D.; Contreras, S.; Coffey, R.; Keane, M. Development of a global energy management system for non-energy intensive multi-site industrial organisations: A methodology. Energy 2017, 136, 16-31. [CrossRef]

42. ICF International. Study on Energy Efficiency and Energy Saving Potential in Industry and on Possible Policy Mechanisms. 2015. Available online: https: / / ec.europa.eu/energy/sites/default/files/documents/151201\%20DG\%20ENER\%20Industrial\%20EE\% 20study\%20-\%20final\%20report_clean_stc.pdf (accessed on 22 February 2021).

43. Malinauskaite, J.; Jouhara, H.; Ahmad, L.; Milani, M.; Montorsi, L.; Venturelli, M. Energy efficiency in industry: EU and national policies in Italy and the UK. Energy 2019, 172, 255-269. [CrossRef]

44. Peters, K.; Malfa, E.; Colla, V. The European steel technology platform's strategic research agenda: A further step for the steel as backbone of EU resource and energy intense industry sustainability. Metall. Ital. 2019, 5, 5-17.

45. International Energy Agency. Available online: https://www.iea.org/reports/iron-and-steel (accessed on 20 July 2021).

46. 2020 World Steel in Figure. Available online: https://www.worldsteel.org/en/dam/jcr:f7982217-cfde-4fdc-8ba0-795ed807f513 /World\%2520Steel\%2520in\%2520Figures\%25202020i.pdf (accessed on 13 April 2021).

47. Rossetti di Valdalbero, D. The Future of European Steel-Innovation and Sustainability in a Competitive World and EU Circular Economy; European Commission: Bruxelles, Belgium, 2017.

48. Fullana Puig, L. Comparative study of Industrial Symbiosis in Italy and Spain. Bachelor's Thesis, Universitat Politècnica de Catalunya, Barcelona, Spain, 2019.

49. Branca, T.; Colla, V.; Algermissen, D.; Granbom, H.; Martini, U.; Morillon, A.; Pietruck, R.; Rosendahl, S. Reuse and Recycling of By-Products in the Steel Sector: Recent Achievements Paving the Way to Circular Economy and Industrial Symbiosis in Europe. Metals 2020, 10, 345. [CrossRef]

50. Worldsteel Association. Steel Industry Co-Products. Available online: https://www.worldsteel.org/en/dam/jcr:1b916a6d-06fd4e84-b35d-c1d911d18df4/Fact_By-products_2018.pdf (accessed on 20 July 2021).

51. Rosendahl, S.; Lundkvist, K.; Haase, B.; Stemne, J.; Andersson, L.; Eriksson, R. Establishing an industrial symbiosis-Key factors and time aspects in steel industry. Matériaux Tech. 2019, 107, 508. [CrossRef]

52. Lundkvist, K.; Rosendahl, S.; Sandberg, E.; Haase, B.; Stemne, J.; Peltola, P.; Eriksson, R. Case study of industrial symbiosis for improved residual material utilisation in the steel industry. Matériaux Tech. 2019, 107, 509. [CrossRef]

53. Di Sante, L.; Cirilli, F.; Angelucci, N. EAF slag: A product no longer a problem. Iron Steel Technol. 2013, 10, 257-265.

54. Fisher, L.V.; Barron, A.R. The recycling and reuse of steelmaking slags-A review. Resour. Conserv. Recycl. 2019, 146, 244-255. [CrossRef]

55. Branca, T.A.; Colla, V.; Valentini, R. A way to reduce environmental impact of ladle furnace slag. Ironmak. Steelmak. 2009, 36, 597-602. [CrossRef]

56. Gomes, H.I.; Funari, V.; Mayes, W.M.; Rogerson, M.; Prior, T.J. Recovery of $\mathrm{Al}$, Cr and V from steel slag by bioleaching: Batch and column experiments. J. Environ. Manag. 2018, 222, 30-36. [CrossRef] [PubMed]

57. Baalamurugan, J.; Ganesh Kumar, V.; Govindaraju, K.; Naveen Prasad, B.; Bupesh Raja, V.; Padmapriya, R. Slag-based nanomaterial in the removal of hexavalent chromium. Int. J. Nanosci. 2018, 17, 1760013. [CrossRef]

58. El-Azim, H.A.; Seleman, M.M.E.-S.; Saad, E.M. Applicability of water-spray electric arc furnace steel slag for removal of cd and $\mathrm{mn}$ ions from aqueous solutions and industrial wastewaters. J. Environ. Chem. Eng. 2019, 7, 102915. [CrossRef]

59. Menad, N.; Kana, N.; Kanari, N.; Pereira, F.; Seron, A. Process for Enhancing the Valuable Metal Recovery from" Electric Arc Furnace"(EAF) Slags. Waste Biomass Valorization 2021, 12, 1-14. [CrossRef]

60. Sun, Y.; Zhang, Z.; Liu, L.; Wang, X. Heat recovery from high temperature slags: A review of chemical methods. Energies 2015, 8, 1917-1935. [CrossRef] 
61. McDonald, I.; Werner, A. Dry slag granulation with heat recovery. In Proceedings of the AISTech-Iron and Steel Technology Conference Proceedings (Association for Iron and Steel Technology, AISTECH), Indianapolis, IN, USA, 5-8 May 2014; Volume 1, pp. 467-473.

62. Oge, M.; Ozkan, D.; Celik, M.B.; Gok, M.S.; Karaoglanli, A.C. An overview of utilization of blast furnace and steelmaking slag in various applications. Mater. Today Proc. 2019, 11, 516-525. [CrossRef]

63. Grillo, F.F.; Coleti, J.; Espinosa, D.C.R.; Oliveira, J.R.D.; Tenório, J.A.S. Zn and Fe recovery from electric arc furnace dusts. Mater. Trans. 2014, 55, 351-356. [CrossRef]

64. Ranya, P.; Nagarajan, P.; Shashikala, A. Eco-Friendly Ggbs Concrete: A State-of-the-Art Review. IOP Conference Series: Materials Science and Engineering; IOP Publishing: Bristol, UK, 2018; p. 012057.

65. Tsakiridis, P.E.; Papadimitriou, G.D.; Tsivilis, S.; Koroneos, C. Utilization of steel slag for portland cement clinker production. J. Hazard. Mater. 2008, 152, 805-811. [CrossRef]

66. Babita, S.; Saurabh, U.; Abhishek, G.K.; Manoj, Y.; Pranjal, B.; Ravi, M.K.; Pankaj, K. Review paper on partial replacement of cement and aggregates with various industrial waste material and its effect on concrete properties. In Recycled Waste Materials; Springer: Berlin/Heidelberg, Germany, 2019; pp. 111-117.

67. Xiao, Z.; Chen, M.; Wu, S.; Xie, J.; Kong, D.; Qiao, Z.; Niu, C. Moisture susceptibility evaluation of asphalt mixtures containing steel slag powder as filler. Materials 2019, 12, 3211. [CrossRef] [PubMed]

68. Skaf, M.; Pasquini, E.; Revilla-Cuesta, V.; Ortega-López, V. Performance and durability of porous asphalt mixtures manufactured exclusively with electric steel slags. Materials 2019, 12, 3306. [CrossRef]

69. Pasetto, M.; Baldo, N. Re-use of industrial wastes in cement bound mixtures for road construction. Environ. Eng. Manag. J. 2018, 17, 417-426. [CrossRef]

70. Nguyen, H.Q.; Lu, D.X.; Le, S.D. Investigation of Using Steel Slag in Hot Mix Asphalt for The Surface Course of Flexible Pavements; IOP Conference Series: Earth and Environmental Science; IOP Publishing: Bristol, UK, 2018; p. 012022.

71. Alnadish, A.; Aman, Y. A study on the economic using of steel slag aggregate in asphalt mixtures reinforced by aramid fiber. Arpn J. Eng. Appl. Sci. 2018, 13, 276-292.

72. Branca, T.A.; Pistocchi, C.; Colla, V.; Ragaglini, G.; Amato, A.; Tozzini, C.; Mudersbach, D.; Morillon, A.; Rex, M.; Romaniello, L. Investigation of (BOF) converter slag use for agriculture in Europe. Rev. De Métallurgie Int. J. Metall. 2014, 111, $155-167$.

73. Pistocchi, C.; Ragaglini, G.; Colla, V.; Branca, T.A.; Tozzini, C.; Romaniello, L. Exchangeable sodium percentage decrease in saline sodic soil after basic oxygen furnace slag application in a lysimeter trial. J. Environ. Manag. 2017, 203, 896-906. [CrossRef] [PubMed]

74. Branca, T.A.; Fornai, B.; Colla, V.; Pistocchi, C.; Ragaglini, G. Application of basic oxygen furnace (bofs) in agriculture: A study on the economic viability and effects on the soil. Environ. Eng. Manag. J. 2019, 18, 1231-1244. [CrossRef]

75. Mohammed, T.A.; Aa, H.; Ma, E.E.-A.; Khm, E.-M. Coral rehabilitation using steel slag as a substrate. Int. J. Env. Prot. 2012, 2, 1-5.

76. Asaoka, S.; Okamura, H.; Morisawa, R.; Murakami, H.; Fukushi, K.; Okajima, T.; Katayama, M.; Inada, Y.; Yogi, C.; Ohta, T. Removal of hydrogen sulfide using carbonated steel slag. Chem. Eng. J. 2013, 228, 843-849. [CrossRef]

77. Gwon, H.S.; Khan, M.I.; Alam, M.A.; Das, S.; Kim, P.J. Environmental risk assessment of steel-making slags and the potential use of ld slag in mitigating methane emissions and the grain arsenic level in rice (Oryza sativa L.). J. Hazard. Mater. 2018, 353, 236-243. [CrossRef]

78. Suda, A.; Yamaguchi, N.; Taniguchi, H.; Makino, T. Arsenic immobilization in anaerobic soils by the application of by-product iron materials obtained from the casting industry. Soil Sci. Plant Nutr. 2018, 64, 210-217. [CrossRef]

79. Baidya, R.; Kumar Ghosh, S.; Parlikar, U.V. Blast furnace flue dust co-processing in cement kiln-a pilot study. Waste Manag. Res. 2019, 37, 261-267. [CrossRef] [PubMed]

80. López-Díaz, A.; Ochoa-Díaz, R.; Grimaldo-León, G.E. Use of bof slag and blast furnace dust in asphalt concrete: An alternative for the construction of pavements. DYNA 2018, 85, 24-30. [CrossRef]

81. Sellitto, M.A.; Murakami, F.K. Industrial symbiosis: A case study involving a steelmaking, a cement manufacturing, and a zinc smelting plant. Chem. Eng. Trans. 2018, 70, 211-216.

82. Porzio, G.F.; Colla, V.; Fornai, B.; Vannucci, M.; Larsson, M.; Stripple, H. Process integration analysis and some economicenvironmental implications for an innovative environmentally friendly recovery and pre-treatment of steel scrap. Appl. Energy 2016, 161, 656-672. [CrossRef]

83. Varga, T.; Bokányi, L.; Török, T.I. On the aqueous recovery of zinc from dust and slags of the iron and steel production technologies. Int. J. Metall. Mater. Eng. 2016, 212, 195-200. [CrossRef]

84. Andersson, A.; Andersson, M.; Mousa, E.; Kullerstedt, A.; Ahmed, H.; Björkman, B.; Sundqvist-Ökvist, L. The potential of recycling the high-zinc fraction of upgraded BF sludge to the desulfurization plant and basic oxygen furnace. Metals $2018,8,1057$. [CrossRef]

85. He, M.; Li, B.; Zhou, W.; Chen, H.; Liu, M.; Zou, L. Preparation and Characteristics of Steel Slag Ceramics from Converter Slag; Springer: Berlin/Heidelberg, Germany, 2018; pp. 13-20.

86. Khaerudini, D.; Prakoso, G.; Insiyanda, D.; Widodo, H.; Destyorini, F.; Indayaningsih, N. Effect of graphite addition into mill scale waste as a potential bipolar plates material of proton exchange membrane fuel cells. J. Phys. Conf. Ser. 2018, $985,012050$.

87. Madias, J. A review on Recycling of Refractories for the Iron and Steel Industry. In Proceedings of the UNITECR 2017-15th Biennial Worldwide Congress, Santiago, Chile, 26-29 September 2017. 
88. Fasolini, S.; Martino, M. Recovery of Spent Refractories: How to Do It and Using Them as Secondary Raw Materials for Refractory Applications. Available online: http://www.indmin.com/events/download.ashx/document/speaker/8915/a0ID000 000ZwxAQMAZ/Presentation (accessed on 22 February 2021).

89. O'Driscoll, M. Recycling Refractories. Available online: http://imformed.com/wp-content/uploads/2017/07/IMFORMEDRefractory-Recycling-Glass-Int-Mar-2016.pdf (accessed on 22 February 2021).

90. World Steel Association. Energy Use in the Steel Industry; World Steel Association: Brussels, Belgium, 2014.

91. Zaccara, A.; Petrucciani, A.; Matino, I.; Branca, T.A.; Dettori, S.; Iannino, V.; Colla, V.; Bampaou, M.; Panopoulos, K. Renewable Hydrogen Production Processes for the Off-Gas Valorization in Integrated Steelworks through Hydrogen Intensified Methane and Methanol Syntheses. Metals 2020, 10, 1535. [CrossRef]

92. Fick, G.; Mirgaux, O.; Neau, P.; Patisson, F. Using biomass for pig iron production: A technical, environmental and economical assessment. Waste Biomass Valor. 2014, 5, 43-55. [CrossRef]

93. Suopajärvi, H.; Umeki, K.; Mousa, E.; Hedayati, A.; Romar, H.; Kemppainen, A.; Wang, C.; Phounglamcheik, A.; Tuomikoski, S.; Norberg, N. Use of biomass in integrated steelmaking-status quo, future needs and comparison to other low-Co2 steel production technologies. Appl. Energy 2018, 213, 384-407. [CrossRef]

94. Kalde, A.; Demus, T.; Echterhof, I.T.; Pfeifer, I.H. Determining the Reactivity of Biochar-Agglomerates to Replace Fossil Coal in Electric Arc Furnace Steelmaking. In Proceedings of the 23rd European Biomass Conference and Exhibition, Vienna, Austria, 1-4 June 2015.

95. Devasahayam, S. Opportunities for simultaneous energy/materials conversion of carbon dioxide and plastics in metallurgical processes. Sustain. Mater. Technol. 2019, 22, e00119. [CrossRef]

96. Todoschuk, T.; Giroux, L.; Ng, K.W. Developments of Biocarbon for Canadian Steel Production; Canadian Carbonization Research Association: Hamilton, ON, Canada, 2016.

97. JISF's. Commitment to a Low Carbon Society. In Activities of Japanese Steel Industry to Combat Global Warming; Japan Iron and Steel Federation: Tokyo, Japan, 2018.

98. Di Sante, L.; Di Donato, A.; Duce, E. The steel plant: The Heart of An Industrial Symbiosis Project. In Proceedings of the 13th Society and Material Conference (SAM13), Pisa, Italy, 20-21 May 2019.

99. European Commission. Available online: https:/ / ec.europa.eu/growth/sectors/chemicals_en (accessed on 15 March 2021).

100. Global Refinery Capacity. Available online: https://www.statista.com/statistics/264333/global-refinery-capacity-for-crude-oil/ (accessed on 20 July 2021).

101. Chopra, S.S.; Khanna, V. Understanding resilience in industrial symbiosis networks: Insights from network analysis. J. Environ. Manag. 2014, 141, 86-94. [CrossRef] [PubMed]

102. Notarnicola, B.; Tassielli, G.; Renzulli, P.A. Industrial symbiosis in the Taranto industrial district: Current level, constraints and potential new synergies. J. Clean. Prod. 2016, 122, 133-143. [CrossRef]

103. Harris, S.; Pritchard, C. Industrial ecology as a learning process in business strategy. Prog. Ind. Ecol. Int. J. 2004, 1, 89-111. [CrossRef]

104. Chertow, M.R.; Lombardi, D.R. Quantifying Economic and Environmental Benefits of Co-Located Firms. Environ. Sci. Technol. 2005, 39, 6535-6541. [CrossRef]

105. Chertow, M.; Miyata, Y. Assessing collective firm behavior: Comparing industrial symbiosis with possible alternatives for individual companies in Oahu, HI. Bus. Strategy Environ. 2011, 20, 266-280. [CrossRef]

106. Won, J.Y.; Kim, J.H.; Lee, S.Y.; Park, H.S. Industrial symbiosis as an integrated business/environment management process: The case of Ulsan industrial complex. In Proceedings of the 2006 International Forum on Strategic Technology, Ulsan, Korea, 18-20 October 2006; pp. 423-428.

107. Petersen, M. Considering Sustainability in the Development of Consumer Goods. Ph.D. Thesis, Technische Universität Hamburg, Hamburg, Germany, 2017.

108. Meinhardt, S.; Kern, C.; Kauffmann, K.; Jahraus, J. Innovative Gestaltung von Geschäftsprozessen in der Konsumgüterindustrie: Marktumfeld-Herausforderungen—Vorgehensmodell_Praxisbeispiele—Handlungsempfehlungen; Dpunkt: Heidelberg, Germany, 2010.

109. Schilling, R. Manufacturing Network Development in Fast-Moving Consumer Goods Industries; Verlag Dr. Kovač: Hamburg, Germany, 2012.

110. Ecover's Glocal Project. Available online: https://www.biobasedpress.eu/2014/05/glocal-project-ecovers-experiment-mallorca/ (accessed on 20 March 2021).

111. Institute for European Studies. Available online: https://www.ies.be/files/Metals_for_a_Climate_Neutral_Europe.pdf (accessed on 2 March 2021).

112. Eurometaux. Available online: https:/ / eurometaux.eu/about-our-industry/key-industry-data/ (accessed on 2 March 2021).

113. Organisation for Economic Cooperation and Development (OECD). Global Material Resources Outlook to 2060: Economic Drivers and Environmental Consequences; OECD Publishing: Paris, France, 2019. [CrossRef]

114. Dessart, F.J.; Bontoux, L. Non-Ferrous Metals Manufacturing: Vision for 2050 and Actions Needed; Publications Office of the European Union: Luxembourg, 2017.

115. EU Strategies on Energy Sector Integration \& Hydrogen. Available online: https://www.european-aluminium.eu/media/29 45/16-06-2020-european-aluminium-on-eu-energy-sector-integration-hydrogen-strategy-policy-roadmaps.pdf (accessed on 3 March 2021). 
116. Circular Aluminium Action Plan: A Strategy for Achieving Aluminium's Full Potential for Circular Economy by 2030. Available online: https:/ / european-aluminium.eu/media/2929/2020-05-13-european-aluminium_circular-aluminium-action-plan.pdf (accessed on 3 March 2021).

117. Changing How We Produce and Consume: New Circular Economy Action Plan Shows the Way to a Climate-Neutral, Competitive Economy of Empowered Consumers. Available online: https://nutriman.net/sites/default/files/2020-03/EU_CircularEconomy-Action_EN.pdf (accessed on 3 March 2021).

118. Industrial Minerals Association-Europe. Available online: https://www.ima-europe.eu/sites/ima-europe.eu/files/ publications/IMA-Europe_Circular\%20Economy\%20Report_2018.pdf (accessed on 3 March 2021).

119. 2018 EuLA Innovation Report. Available online: https://www.eula.eu/2018-eula-innovation-report/ (accessed on 3 March 2021).

120. European Environment Agency. Available online: https://www.eea.europa.eu/data-and-maps/indicators/use-of-freshwaterresources-2/assessment-3 (accessed on 3 March 2021).

121. ECWRTI. Available online: https:/ / ecwrti.eu/ (accessed on 3 March 2021).

122. NextGen. Available online: https:/ / www.kwrwater.nl/en/projecten/nextgen/ (accessed on 8 March 2021).

123. Bürger, G. Reuse of Treated Wastewater in Industrial Symbiosis. Master's Thesis, Number: 2019-3. Water and Environmental Engineering Department of Chemical Engineering, Lund University, Lund, Sweden, June 2019.

124. Kalundborg Symbiosis. Available online: http:/ / www.symbiosis.dk/en/ (accessed on 8 March 2021).

125. IEA-International Energy Agency. Cement Technology Roadmap 2009: Carbon Emissions Reductions up to 2050; OECD Publishing: Paris, France, 2009.

126. World Business Council for Sustainable Development WBCSD/CSI. 2009. Available online: https:/ ficem.org/CIC-descargas/ Suiza/CSI/Cement-Industry-Energy-and-CO2-Performance_Getting-the-Numbers-Right.pdf (accessed on 8 March 2021).

127. Processes4Planet Roadmap 2050. Available online: https:/ / www.spire2030.eu/content/p4planet-roadmap-2050 (accessed on 8 March 2021).

128. Van Oss, H.G.; Padovani, A.C. Cement manufacture and the environment: Part I: Chemistry and technology. J. Ind. Ecol. 2002, 6, 89-105.

129. Towards a Sustainable Cement Industry. Substudy 8: Climate Change. Available online: https://www.wbcsd.org/SectorProjects/Cement-Sustainability-Initiative/Resources/Toward-a-Sustainable-Cement-Industry (accessed on 8 March 2021).

130. Guidelines on Co-Processing Waste Materials in Cement Production. Available online: https://www.geocycle.com/sites/ geocycle/files/atoms/files/co-processing_supporting_document_giz-holcim_guidelines_0.pdf (accessed on 8 March 2021).

131. Reijnders, L. The cement industry as a scavenger in industrial ecology and the management of hazardous substances. J. Ind. Ecol. 2007, 11, 15-25. [CrossRef]

132. Feiz, R.; Ammenberg, J.; Baas, L.; Eklund, M.; Helgstrand, A.; Marshall, R. Improving the $\mathrm{CO}_{2}$ performance of cement, part I: Utilizing life-cycle assessment and key performance indicators to assess development within the cement industry. J. Clean. Prod. 2015, 98, 272-281. [CrossRef]

133. Ammenberg, J.; Baas, L.; Eklund, M.; Feiz, R.; Helgstrand, A.; Marshall, R. Improving the $\mathrm{CO}_{2}$ performance of cement, part III: The relevance of industrial symbiosis and how to measure its impact. J. Clean. Prod. 2015, 98, 145-155. [CrossRef]

134. Hashimoto, S.; Fujita, T.; Geng, Y.; Nagasawa, E. Realizing $\mathrm{CO}_{2}$ emission reduction through industrial symbiosis: A cement production case study for Kawasaki. Resour. Conserv. Recycl. 2010, 54, 704-710. [CrossRef]

135. Facts \& Figures of Ceramic Industry. Available online: http:/ / cerameunie.eu/ceramic-industry/facts-figures / (accessed on 8 March 2021).

136. The Ceramic Product and Production Process and the Circular Economy. Available online: https://www.ceramica.info/en/ articoli/ceramic-process-circular-economy / (accessed on 8 March 2021).

137. Baraldi, L.; ACIMAC. World production and consumption of ceramic tiles. Tile Int. 2017, 3, 42-48.

138. ASCER-The Spanish Ceramic Tile Manufacturers' Association. Available online: https://ascer.es/ascerPresentacion.aspx?lang= en-GB\&cual=presentacion (accessed on 8 March 2021).

139. Agrafiotis, C.; Tsoutsos, T. Energy saving technologies in the European ceramic sector: A systematic review. Appl. Therm. Eng. 2001, 21, 1231-1249. [CrossRef]

140. Ceramic Industry Roadmap: Paving the Way to 2050. Available online: http: / cerameunie.eu/topics/cerame-unie-sectors / cerame-unie/ceramic-industry-roadmap-paving-the-way-to-2050/ (accessed on 9 March 2021).

141. Cerame-Unie, The European Ceramic Industry Association. Available online: http:/ / cerameunie.eu/ (accessed on 20 July 2021 ).

142. Almeida, M.I.; Dias, A.C.; Demertzi, M.; Arroja, L. Environmental profile of ceramic tiles and their potential for improvement. J. Clean. Prod. 2016, 131, 583-593. [CrossRef]

143. Resolution no. 16604 of 23/10/2017 Associated with the Regional Law on the Circular Economy, Regione Emilia Romagna, Italy. 2017. Available online: https:/ / ambiente.regione.emilia-romagna.it/it/rifiuti/documenti/sottoprodotti/det_16604_2017 _sottoprodotti-ceramici/@@download/file/Det_16604_2017_sottoprodotti\%20ceramici.pdf (accessed on 1 July 2021).

144. Carlini, M.; Castellucci, S.; Mennuni, A.; Ferrelli, S.; Felicioni, M.A. Application of a Circular \& Green Economy Model to a Ceramic Industrial District: An Italian Case Study. In Proceedings of the AIP Conference Proceedings, Tangerang Selatan, Indonesia, 19-20 November 2020. 
145. Kaya, M. Recovery of metals and nonmetals from electronic waste by physical and chemical recycling processes. Waste Manag. 2016, 57, 64-90. [CrossRef]

146. Widmer, R.; Oswald-Krapf, H.; Sinha-Khetriwal, D.; Schnellmann, M.; Böni, H. Global perspectives on e-waste. Environ. Impact Assess. Rev. 2005, 25, 436-458. [CrossRef]

147. Ghosh, B.; Ghosh, M.K.; Parhi, P.; Mukherjee, P.S.; Mishra, B.K. Waste printed circuit boards recycling: An extensive assessment of current status. J. Clean. Prod. 2015, 94, 5-19. [CrossRef]

148. European Commission. Critical Raw Materials for the EU: Report of The Ad-Hoc Working Group on Defining Critical Raw Materials; European Commission: Brussels, Belgium, 2010.

149. EU Commission. Report of the Ad-hoc Working Group on Defining Critical Raw Materials. 2014. Available online: http: / / ec.europa.eu/enterprise/policies/raw-materials/critical/index_en.htm (accessed on 10 March 2021).

150. Drabik, E.; Rizos, V. Prospects for Electric Vehicle Batteries in a Circular Economy; Centre for European Policy Studies: Brussels, Belgium, 2018.

151. International Association of Electronic Waste Producer Responsibility Organisations. Available online: https://weee-forum.org/ (accessed on 9 March 2021).

152. WEEE Forum. International E-Waste Day. Available online: https://weee-forum.org/iewd-about/ (accessed on 10 March 2021).

153. Huisman, J.; Habib, H.; Brechu, M.G.; Downes, S.; Herreras, L.; Løvik, A.N.; Wäger, P.; Cassard, D.; Tertre, F.; Mählitz, P.; et al. ProSUM: Prospecting Secondary Raw Materials in The Urban Mine and Mining Wastes. In 2016 Electronics Goes Green 2016+(EGG); IEEE: Piscataway, NJ, USA, 2016; pp. 1-8.

154. Marconi, M.; Gregori, F.; Germani, M.; Papetti, A.; Favi, C. An approach to favor industrial symbiosis: The case of waste electrical and electronic equipment. Procedia Manuf. 2018, 21, 502-509. [CrossRef]

155. Marra, A.; Cesaro, A.; Belgiorno, V. The recovery of metals from WEEE: State of the art and future perspectives. Glob. Nest J. 2018, 20, 679-694.

156. Bunse, K.; Vodicka, M.; Schönsleben, P.; Brülhart, M.; Ernst, F.O. Integrating energy efficiency performance in production management-gap analysis between industrial needs and scientific literature. J. Clean. Prod. 2011, 19, 667-679. [CrossRef]

157. Wu, J.; Wang, R.; Pu, G.; Qi, H. Integrated assessment of exergy, energy and carbon dioxide emissions in an iron and steel industrial network. Appl. Energy 2016, 183, 430-444. [CrossRef]

158. He, K.; Wang, L. A review of energy use and energy-efficient technologies for the iron and steel industry. Renew. Sustain. Energy Rev. 2017, 70, 1022-1039. [CrossRef]

159. Birat, J.P.; Colla, V.; Malfa, E.; Thomas, J.S. SUSTAINABLE steel production for the 2030s: The vision of the European Steel Technology Platform's Strategic Research Agenda ESTEP's SRA. In Proceedings of the Technical proceedings of the 2014 NSTI Nanotechnology Conference and Expo, Washington, DC, USA, 15-18 June 2014; pp. 238-241.

160. Roudier, S.; Sancho, L.D.; Remus, R.; Aguado-Monsonet, M. Best Available Techniques (BAT) Reference Document for Iron and Steel Production: Industrial Emissions Directive 2010/75/EU: Integrated Pollution Prevention and Control. (No. JRC69967) Joint Research Centre (Seville Site). Available online: https://ideas.repec.org/p/ipt/iptwpa/jrc78091.html (accessed on 1 July 2021).

161. Matino, I.; Dettori, S.; Colla, V.; Zaccara, A.; Petrucciani, A.; Weber, V.; Salame, S.; Wolff, A. Advanced Modelling for Forecasting Off-Gas, Steam and Electricity Production and Demand in Integrated Steelworks: The GASNET Model Library. In Proceedings of the European Steel Days ESTAD, Dusseldorf, Germany, 24-28 June 2019.

162. Matino, I.; Dettori, S.; Colla, V.; Weber, V.; Salame, S. Forecasting blast furnace gas production and demand through echo state neural network-based models: Pave the way to off-gas optimized management. Appl. Energy 2019, 253, 113578. [CrossRef]

163. Colla, V.; Matino, I.; Dettori, S.; Cateni, S.; Matino, R. Reservoir Computing Approaches Applied to Energy Management in Industry. In Proceedings of the International Conference on Engineering Applications of Neural Networks, Hersonissos, Greece, 24-26 May 2019; pp. 66-79.

164. Dettori, S.; Matino, I.; Colla, V.; Speets, R. Deep Echo State Networks in Industrial Applications. In Proceedings of the IFIP International Conference on Artificial Intelligence Applications and Innovations, Halkidiki, Greece, 5-7 June 2020 ; pp. 53-63.

165. Dettori, S.; Matino, I.; Colla, V.; Speets, R. A Deep Learning-based approach for forecasting off-gas production and consumption in the blast furnace. Neural Comput. Appl. 2021. [CrossRef]

166. Matino, I.; Dettori, S.; Catellano, A.; Matino, R.; Mocci, C.; Vannocci, M.; Maddaloni, A.; Wolff, A. Machine Learning-Based Models for Supporting Optimal Exploitation of Process Off-Gases in Integrated Steelworks. In Advances in Intelligent Systems and Computing; Springer: Berlin/Heidelberg, Germany, 2021. [CrossRef]

167. Colla, V.; Matino, I.; Dettori, S.; Petrucciani, A.; Zaccara, A.; Weber, V.; Salame, S.; Zapata, N.; Bastida, S.; Wolff, A.; et al. Assessing the efficiency of the off-gas network management in integrated steelworks. Matériaux Tech. 2019, 107, 104. [CrossRef]

168. Colla, V.; Matino, I.; Cirilli, F.; Jochler, G.; Kleimt, B.; Rosemann, H.; Unamuno, I.; Tosato, S.; Gussago, F.; Baragiola, S.; et al. Improving energy and resource efficiency of electric steelmaking through simulation tools and process data analyses. Matériaux Tech. 2016, 104, 602. [CrossRef]

169. Matino, I.; Colla, V.; Baragiola, S. Electric energy consumption and environmental impact in unconventional EAF steelmaking scenarios. Energy Procedia 2017, 105, 3636-3641. [CrossRef]

170. Matino, I.; Colla, V.; Baragiola, S. Quantification of energy and environmental impacts in uncommon electric steelmaking scenarios to improve process sustainability. Appl. Energy 2017, 207, 543-552. [CrossRef] 
171. Porzio, G.F.; Colla, V.; Matarese, N.; Nastasi, G.; Branca, T.A.; Amato, A.; Fornai, B.; Vannucci, M.; Bergamasco, M. Process integration in energy and carbon intensive industries: An example of exploitation of optimization techniques and decision support. Appl. Therm. Eng. 2014, 70, 1148-1155. [CrossRef]

172. Larsson, M.; Wang, C.; Dahl, J.; Wedholm, A.; Samuelsson, C.; Magnusson, M.; Olov Lampinen, H.; Su, F.; Grip, C.E. Improved energy and material efficiency using new tools for global optimisation of residue material flows. Int. J. Green Energy 2006, 3 , 127-137. [CrossRef]

173. Alcamisi, E.; Matino, I.; Colla, V.; Maddaloni, A.; Romaniello, L.; Rosito, F. Process integration solutions for water networks in integrated steel making plants. Chem. Eng. Trans. 2015, 45, 37-42.

174. Colla, V.; Matino, I.; Branca, T.A.; Fornai, B.; Romaniello, L.; Rosito, F. Efficient use of water resources in the steel industry. Water 2017, 9, 874. [CrossRef]

175. Wolff, A.; Sonnenschein, D.; Bialek, S.; Stranziger, B.; Schlimbach, J.; Hillmann, C. Prediction of the Temperature Distribution in The Hot Blast Stove with A Switching Kalman Filter. In Proceedings of the METEC \& 4th ESTAD, Düsseldorf, Germany, 24-28 June 2019.

176. Mazur, D.; Kay, J.; Mazur, K.; Venne, B. The value of integrating power and process for the metals industry. Iron Steel Technol. 2018, 15, 56-62.

177. Hadera, H.; Ekström, J.; Sand, G.; Mäntysaari, J.; Harjunkoski, I.; Engell, S. Integration of production scheduling and energy-cost optimization using Mean Value Cross Decomposition. Comput. Chem. Eng. 2019, 129, 106436. [CrossRef]

178. Marchiori, F.; Benini, M.; Cateni, S.; Colla, V.; Vignali, A.; Ebel, A.; Neuer, M.; Piedimonte, L. Agent-based approach for energy demand-side management. Stahl Und Eisen 2018, 138, 25-29.

179. Marchiori, F.; Belloni, A.; Benini, M.; Cateni, S.; Colla, V.; Ebel, A.; Lupinelli, M.; Nastasi, G.; Neuer, M.; Pietrosanti, C.; et al. Integrated Dynamic Energy Management for Steel Production. Energy Procedia 2017, 105, 2772-2777. [CrossRef]

180. Johansson, M.T. Improved energy efficiency within the Swedish steel industry-The importance of energy management and networking. Energy Effic. 2015, 8, 713-744. [CrossRef]

181. Barthe, P.; Chaugny, M.; Roudier, S.; Delgado Sancho, L. Best Available Techniques (BAT) Reference Document for The Refining of Mineral Oil and Gas; JRC Science and Policy Report EUR 27140EN; European Commission: Brussels, Belgium, 2015.

182. Jochem, E. Energy end-use efficiency. In World Energy Assessment: Energy and the Challenge of Sustainability; United Nation Developed Program: New York, NY, USA, 2015.

183. Intelligent Energy Europe. Available online: https:/ /ec.europa.eu/easme/en/section/energy/intelligent-energy-europe (accessed on 15 March 2021).

184. Decision No 1639/2006/Ec of the European Parliament and of the Council of 24 October 2006. Available online: https:/ / eur-lex. europa.eu/legal-content/EN/ALL/?uri=celex\%3A32006D1639 (accessed on 15 March 2021).

185. SAVE Sub-Program, Specific Actions for Vigorous Energy Efficiency. Available online: https://cordis.europa.eu/article/id/720specific-actions-for-vigorous-energy-efficiency-save (accessed on 15 March 2021).

186. Metals for a Climate Neutral Europe-A 2050 Blueprint, the Institute for European Studies. Available online: https://www. eurometaux.eu/media/1997/exec-summary-metals-2050.pdf (accessed on 15 March 2021).

187. Curry, J.A.; Ismay, M.J.; Jameson, G.J. Mine operating costs and the potential impacts of energy and grinding. Miner. Eng. 2014, 56, 70-80. [CrossRef]

188. McLellan, B.; Corder, G.; Giurco, D.; Ishihara, K. Renewable energy in the minerals industry: A review of global potential. J. Clean. Prod. 2012, 32, 32-44. [CrossRef]

189. Sánchez, J.P.P. Solar Energy Applications in Mining: A Case Study. In Energy Efficiency in the Minerals Industry; Awuah-Offei, K., Ed.; Springer: Berlin/Heidelberg, Germany, 2018; pp. 273-285.

190. Terblanche, P.J.; Kearney, M.P.; Hearn, C.S.; Knights, P.F. Technology Selection and Sizing of On-Board Energy Recovery Systems to Reduce Fuel Consumption of Diesel-Electric Mine Haul Trucks. In Energy Efficiency in the Minerals Industry; Springer: Berlin/Heidelberg, Germany, 2018; pp. 301-333.

191. Morán, L.; Sbarbaro, D.; Ortega, F.; Espinoza, J. Electrical Energy Consumption Characterization of Open-Pit Mining and Mineral Processing Operations Towards The Use of Renewable Energy Sources. In Industry Applications Society Annual Meeting; IEEE: Piscataway, NJ, USA, 2019; pp. 1-6.

192. Abdi-Oskouei, M.; Awuah-Offei, K. Role of the Operator in Dragline Energy Efficiency. In Energy Efficiency in the Minerals Industry; Springer: Berlin/Heidelberg, Germany, 2018; pp. 181-194.

193. Bouchard, J.; Sbarbaro, D.; Desbiens, A. Plant Automation for Energy-Efficient Mineral Processing. In Energy Efficiency in the Minerals Industry; Awuah-Offei, K., Ed.; Springer: Berlin/Heidelberg, Germany, 2018; pp. 233-250.

194. Hoekstra, A.Y. The water footprint of industry. In Assessing and Measuring Environmental Impact and Sustainability; Klemeš, J.J., Ed.; Butterworth-Heinemann: Oxford, UK, 2015; pp. 221-254.

195. Qian, Y. Sustainable management of water resources. Engineering 2016, 2, 23-25. [CrossRef]

196. Brandt, M.; Middleton, R.; Wheale, G.; Schulting, F. Energy efficiency in the water industry, a global research project. Water Pract. Technol. 2011, 6, wpt2011028. [CrossRef]

197. Carns, K. Bringing Energy Efficiency to the Water and Wastewater Industry: How Do We Get There? Proc. Water Environ. Fed. 2005, 7, 7650-7659. [CrossRef] 
198. Zhang, J.; Cao, S.; Yu, L.; Zhou, Y. Comparison of combined cooling, heating and power (CCHP) systems with different cooling modes based on energetic, environmental and economic criteria. Energy Convers. Manag. 2018, 160, 60-73. [CrossRef]

199. Madlool, N.A.; Saidur, R.; Rahim, N.A.; Kamalisarvestani, M. An overview of energy savings measures for cement industries. Renew. Sustain. Energy Rev. 2013, 19, 18-29. [CrossRef]

200. Schorcht, F.; Kourti, I.; Scalet, B.M.; Roudier, S.; Sancho, L.D. Best Available Techniques (BAT) Reference Document for The Production of Cement, Lime and Magnesium Oxide; European Commission Joint Research Centre Institute for Prospective Technological Studies: Luxembourg, 2013.

201. Mokhtar, A.; Nasooti, M. A decision support tool for cement industry to select energy efficiency measures. Energy Strategy Rev. 2020, 28, 100458. [CrossRef]

202. Detwiler, R.J.; Tennis, P.D. The Use of Limestone in Portland Cement: A State-of-the-Art Review; Portland Cement Association: Skokie, IL, USA, 1996.

203. Atmaca, A.; Yumrutaş, R. Analysis of the parameters affecting energy consumption of a rotary kiln in cement industry. Appl. Therm. Eng. 2014, 66, 435-444. [CrossRef]

204. European Commission. IPCC Reference Document on Best Available Techniques (BAT) in the Ceramic Manufacturing Industry. European Commission, Institute for Prospective Technological Studies, Sevilla, Spain. Available online: http://eippcb.jrc.es/ reference/BREF/cer_bref_0807.pdf (accessed on 15 March 2021).

205. Energy Efficiency in Ceramics Processing: Practical Worksheets for Industry. Available online: https://www.tangram.co.uk/TIEnergy\%20Worksheets\%20(Ceramics)\%20-\%20Tangram.pdf (accessed on 15 March 2021).

206. Ibn-Mohammed, T.; Randall, C.A.; Mustapha, K.B.; Guo, J.; Walker, J.; Berbano, S.; Koh, S.C.L.; Wang, D.; Sinclair, D.C.; Reaney, I.M. Decarbonising ceramic manufacturing: A techno-economic analysis of energy efficient sintering technologies in the functional materials sector. J. Eur. Ceram. Soc. 2019, 39, 5213-5235. [CrossRef]

207. Industrial Decarbonisation \& Energy Efficiency Roadmaps to 2050 Ceramic Sector. Available online: https://assets.publishing. service.gov.uk/government/uploads/system/uploads/attachment_data/file/416676/Ceramic_Report.pdf (accessed on 15 March 2021). 